University of New Hampshire

University of New Hampshire Scholars' Repository

Faculty Publications

Winter 1-24-2022

\title{
Future of Winter in Northeastern North America: Climate Indicators Portray Warming and Snow Loss that will Impact Ecosystems and Communities
}

\author{
Elizabeth Burakowski \\ USNH, elizabeth.burakowski@unh.edu \\ Alix Contosta \\ University of New Hampshire \\ Danielle Grogan \\ University of New Hampshire, Durham, danielle.grogan@unh.edu \\ Sarah Nelson \\ Appalachian Mountain Club (AMC), snelson@outdoors.org \\ Sarah Garlick \\ Hubbard Brook Foundation, sgarlick@hubbardbrookfoundation.org \\ Follow this and additional works at: https://scholars.unh.edu/faculty_pubs \\ See next page for additional authors \\ Part of the Environmental Indicators and Impact Assessment Commons, and the Other Earth Sciences \\ Commons
}

\section{Recommended Citation}

Burakowski, Elizabeth; Contosta, Alix; Grogan, Danielle; Nelson, Sarah; Garlick, Sarah; and Casson, Nora, "Future of Winter in Northeastern North America: Climate Indicators Portray Warming and Snow Loss that will Impact Ecosystems and Communities" (2022). Northeastern Naturalist. 1394.

https://scholars.unh.edu/faculty_pubs/1394

This Article is brought to you for free and open access by University of New Hampshire Scholars' Repository. It has been accepted for inclusion in Faculty Publications by an authorized administrator of University of New Hampshire Scholars' Repository. For more information, please contact Scholarly.Communication@unh.edu. 


\section{Authors}

Elizabeth Burakowski, Alix Contosta, Danielle Grogan, Sarah Nelson, Sarah Garlick, and Nora Casson 


\title{
Future of Winter in Northeastern North America: Climate Indicators Portray Warming and Snow Loss that will Impact Ecosystems and Communities
}

\author{
Elizabeth A. Burakowski ${ }^{1, *}$, Alexandra R. Contosta ${ }^{1}$, Danielle Grogan ${ }^{1}$, \\ Sarah J. Nelson ${ }^{2}$, Sarah Garlick ${ }^{3}$, and Nora Casson ${ }^{4}$
}

\begin{abstract}
Winters in northeastern North America have warmed faster than summers, with impacts on ecosystems and society. Global climate models (GCMs) indicate that winters will continue to warm and lose snow in the future, but uncertainty remains regarding the magnitude of warming. Here, we project future trends in winter indicators under lower and higher climate-warming scenarios based on emission levels across northeastern North America at a fine spatial scale $\left(1 / 16^{\circ}\right)$ relevant to climate-related decision making. Under both climate scenarios, winters continue to warm with coincident increases in days above freezing, decreases in days with snow cover, and fewer nights below freezing. Deep snowpacks become increasingly short-lived, decreasing from a historical baseline of 2 months of subnivium habitat to $<1$ month under the warmer, higher-emissions climate scenario. Warmer winter temperatures allow invasive pests such as Adelges tsugae (Hemlock Woolly Adelgid) and Dendroctonus frontalis (Southern Pine Beetle) to expand their range northward due to reduced overwinter mortality. The higher elevations remain more resilient to winter warming compared to more southerly and coastal regions. Decreases in natural snowpack and warmer temperatures point toward a need for adaptation and mitigation in the multi-million-dollar winter-recreation and forest-management economies.
\end{abstract}

\section{Introduction}

The cold season in northeastern North America is warming at a faster rate than the warm season (Collins et al. 2013, Donat et al. 2013, Karmalkar and Bradley 2017, Wuebbles et al. 2017). Over the past 100 years, minimum winter temperatures have increased $0.16{ }^{\circ} \mathrm{C} /$ decade, with commensurate reductions in snowpack duration and frequency of extreme cold conditions, as well as increased proportion of winter precipitation falling as rain instead of snow (Burakowski et al. 2008; Contosta et al. 2019, 2020; Huntington et al. 2004). Winter heat waves have become more common and have a disproportionate impact on baseline streamflow (Casson et al. 2019).

The rate and magnitude of winter warming throughout the region has profound implications for ecosystems and society. Forested ecosystems in northeastern North America rely on deep snowpacks for insulation of soils (Decker et al. 2003, Hardy et al. 2001, Sanders-DeMott et al. 2018, Sorensen et al. 2018, Tatariw et al. 2017,

\footnotetext{
${ }^{1}$ Institute for the Study of Earth, Oceans, and Space, University of New Hampshire, Durham, NH 03824. ${ }^{2}$ Appalachian Mountain Club, Gorham, NH 03581. ${ }^{3}$ Hubbard Brook Research Foundation, North Woodstock, NH 03262. ${ }^{4}$ University of Winnipeg, Department of Geography, Winnipeg, MB R3B2E9, Canada. *Corresponding author Elizabeth.burakowski@unh.edu.
}

Manuscript Editor: Thomas Maier 
Templer et al. 2012), winter recreation (Burakowski and Magnusson 2012, Dawson et al. 2013, Hagenstad et al. 2018, Hamilton et al. 2007, Scott et al. 2020), and subnivium habitat (Pauli et al. 2013, Penczykowski et al. 2017, Zhu et al. 2019). Sustained cold temperatures reduce overwintering survival of invasive forest pests (Dodds et al. 2018, Dukes et al. 2009, Paradis et al. 2008, Skinner et al. 2003, Weed et al. 2013), and a combination of below-freezing conditions and a deep, persistent snowpack facilitate winter forest harvest (Rittenhouse and Rissman 2015). In addition to these changes in average conditions, extreme winter weather events such as rain-on-snow, rain-on-frozen ground, and winter heat waves can produce floods that damage inland and coastal infrastructure (Casson et al. 2019, Wake et al. 2019). While retrospective analyses can inform policymakers about ongoing impacts of changing winters, statistically downscaled future-climate projections can provide regional planners, natural resource managers, community leaders, and others with high spatial resolution data relevant for climate-related decision making at a local scale (Horne et al. 2021 [this issue]).

The $4^{\text {th }}$ National Climate Assessment (NCA4; Wuebbles et al. 2017) used the LOcalized Constructed Analogs dataset (LOCA; Pierce et al. 2014) of daily minimum temperature, maximum temperature, and precipitation downscaled from a coarse spatial resolution of $1-2^{\circ}(\sim 100-200 \mathrm{~km})$ to a finer spatial resolution of $1 / 16^{\circ}(\sim 7$ $\mathrm{km})$ to assess changes in future climate across the United States. The NCA4 notes that winters have warmed 3 times faster than summers over the past few decades (1981-2010), and that winters will continue to experience this warming trend through the $21^{\text {st }}$ century. This winter warming and loss of seasonality will impact both natural ecosystems and human communities of northeastern North America, particularly in rural areas (Dupigny-Giroux et al. 2018, Thibeault and Seth 2014). The regional scope of the NCA4 report, however, precludes analysis of town, watershed, conservation management areas, or other relatively small delineations that are relevant to planners and managers. Here, we combine the LOCA dataset with a process-based global hydrologic model (Grogan et al. 2020) to understand how winter indicators are projected to change over the $21^{\text {st }}$ century at a spatial scale more relevant to local decision-making.

\section{Data and Methods}

\section{Future climate projections}

We used the LOCA method to statistically downscale daily minimum and maximum temperature and precipitation from 29 global climate models (Pierce et al. 2014) at $1 / 16^{\circ}$ spatial resolution for the northeastern United States and southeastern Canada (Fig. 1). The LOCA downscaling method uses data at a single-day scale rather than the traditionally used 30-day average, resulting in a statistically downscaled model product that provides better representation of daily temperature and precipitation extremes and distributions, compared to traditional analog downscaling techniques, such as bias correction with spatial disaggregation (BCSD; Wood et al. 2004), constructed analogs (CA; Hidalgo et al. 2008), bias correction with 
constructed analogs (BCCA; Maurer et al. 2010), and multivariate adapted constructed analogs (MACA; Abatzoglou and Brown 2012). The LOCA dataset most recently served as the basis for the NCA4, replacing the previous BCCA dataset (Wuebbles et al. 2017).

The LOCA daily dataset future projections include 2 representative concentration pathway (RCP) scenarios. Under the lower RCP4.5, emissions of greenhouse gases peak mid-century and radiative forcing stabilizes at $4.5 \mathrm{~W} \mathrm{~m}^{-2}$ by 2100 , equivalent to about $550 \mathrm{ppm} \mathrm{CO}_{2}$ and a global temperature increase of $\sim 2{ }^{\circ} \mathrm{C}$ (Thomson et al. 2011). The higher RCP8.5 scenario is characterized by a tripling of carbon emissions and increase of global temperature of $\sim 4{ }^{\circ} \mathrm{C}$ by 2100 , with concentrations of $\mathrm{CO}_{2}$ exceeding $900 \mathrm{ppm}$ (Riahi et al. 2011).

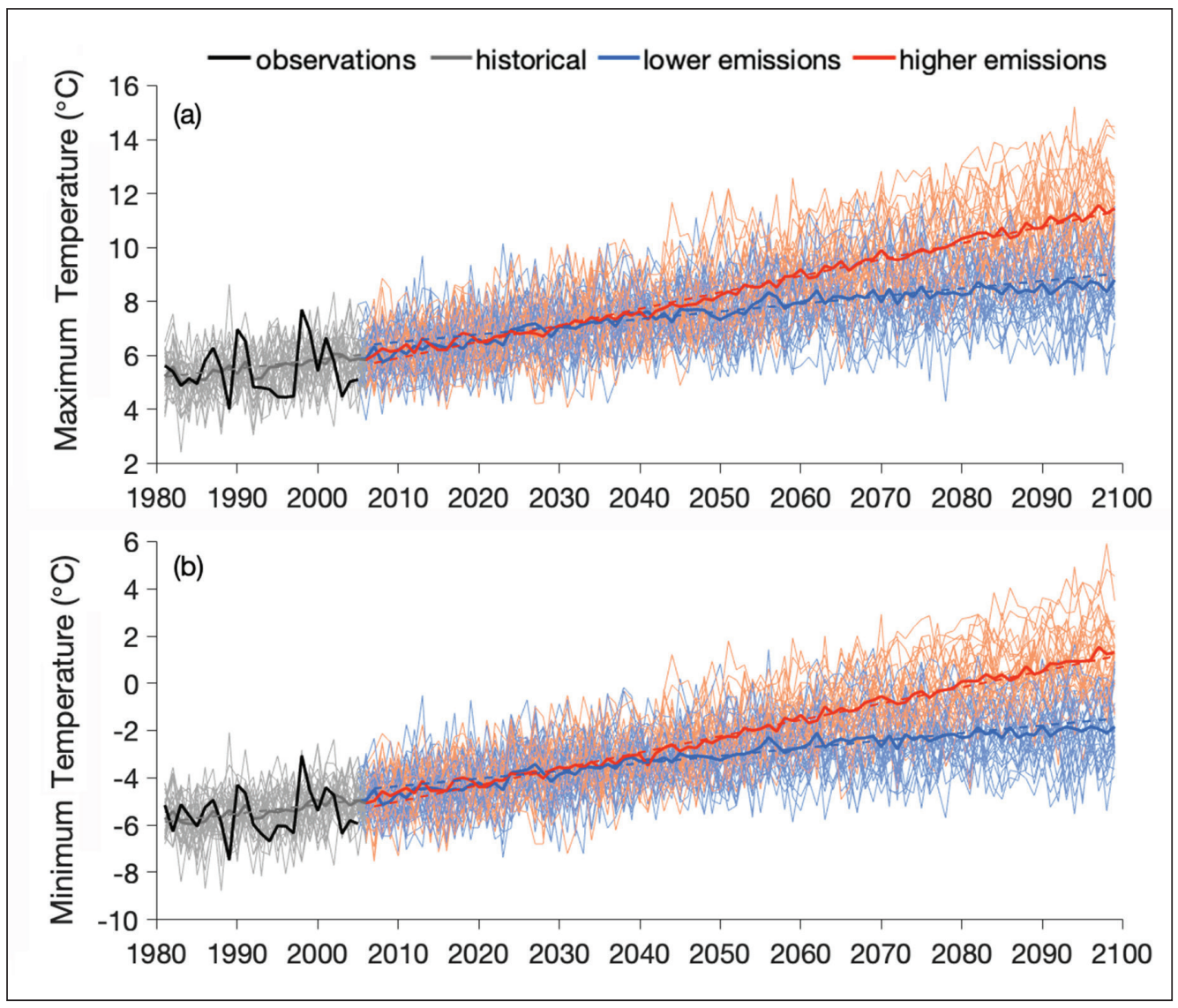

Figure 1. Cool season (November-May) (a) maximum temperature and (b) minimum temperature time series, 1980-2099. The thin lines represent individual model runs and thick lines are the Coupled Model Intercomparison Project 5 (CMIP5) model ensemble mean. Grey lines are the recent historical scenario (1980-2005), blue lines are the lower-emissions scenario (RCP4.5), red lines are the higher-emissions scenario (RCP8.5), and the black lines show observations (Livneh et al. 2013). Dashed lines are Sen's slope for the ensemble mean, $P<0.01$. 


\section{Gridded observations}

We completed model validation for historical (1980-2005) monthly and coldseason (November-May) precipitation, maximum temperature, and minimum temperature using the Livneh et al. $(2013,2014)$ gridded observational dataset. We gridded data to $1 / 16^{\circ}$ spatial resolution from over 20,000 National Oceanic and Atmospheric Administration (NOAA) Cooperative (COOP) observer stations in the conterminous United States. Additional validation of LOCA was completed in the NCA4 (Wuebbles et al. 2017).

\section{Modeled daily snow water equivalent, snowfall, and rainfall}

The University of New Hampshire Water Balance Model (WBM; Grogan 2016, Vörösmarty et al. 1998, Wisser et al. 2010) is a process-based, gridded hydrologic model that simulates major stocks and fluxes of the terrestrial water cycle, including snowpack, partitioning of liquid and solid precipitation, runoff, groundwater storage, soil moisture, and evapotranspiration, among other variables. We ran the WBM using the LOCA daily mean temperature and precipitation fields as inputs (Grogan et al. 2020), and derived climate metrics using outputs of LOCA-WBM snowpack (snow water equivalent or SWE, mm), snowfall (water equivalent or w.e., $\mathrm{mm} /$ day), and rainfall ( $\mathrm{mm} /$ day).

WBM runoff has been validated extensively in northeastern North America and other seasonally snow-covered, forested regions in the temperate latitudes (see Grogan et al. 2016, 2020 and references therein). The LOCA-WBM simulation used here has been previously validated to study snowpack-disappearance date in the northeastern US during the "vernal window" or winter-spring shoulder season (Grogan et al. 2020). This version of WBM used discretized 250-m elevation bins derived from a 30-m digital elevation model to apply a temperature lapse rate of $-6.4{ }^{\circ} \mathrm{C} / 1000 \mathrm{~m}$ that more accurately accounts for rain-snow partitioning and snowpack evolution in complex terrain (Grogan et al. 2020). In WBM, precipitation falls as rain at temperatures greater than $1{ }^{\circ} \mathrm{C}$, and as snow when mean temperatures are less than $-1^{\circ} \mathrm{C}$. Detailed LOCA-WBM model validation of SWE and runoff is described in Grogan et al. (2020).

\section{Cold-season climate indicators}

We calculated changes in cold-season climatology (1 November-31 May) for maximum temperature, minimum temperature, total precipitation, and total snowfall as a regional average for the entire study area for the historical period (1981-2005) and compared them to early (2010-2039), mid- (2040-2069), and late- (2070-2099) century projections. In addition to cold-season climatology, we calculated historical and future changes in the winter climate indicators, as outlined by Contosta et al. (2019). Several of the metrics we studied are standard ones used by the World Meteorological Organization, including ice days (daily maximum temperature $<0{ }^{\circ} \mathrm{C}$ ), frost days (daily minimum temperature $<0{ }^{\circ} \mathrm{C}$ but with maximum temperature $>0{ }^{\circ} \mathrm{C}$ ), and thaw days (daily maximum temperature $>0{ }^{\circ} \mathrm{C}$ ).

We derived additional indicators from published literature, expert input, and stakeholder engagement meetings (see Appendix S1 in Contosta et al. 2019). For 
example, we projected changes in extreme minimum temperature thresholds, -18 ${ }^{\circ} \mathrm{C}$ and $-30{ }^{\circ} \mathrm{C}$, for kill days of Dendroctonus frontalis Zimmermann (Southern Pine Beetle) and Adelges tsugae (Annand) (Hemlock Woolly Adelgid [HWA]), respectively. The Culicidae (mosquito) kill day threshold of $-5{ }^{\circ} \mathrm{C}$ doubles as an indicator for snowmaking days in the northeastern US and eastern Canada (Scott et al. 2003, 2008; Wilson et al. 2018). We estimated the projected percentage change in snowmaking days that would apply to the 197 downhill and Nordic ski resorts in the northeastern United States and southeastern Canada from the ensemble mean Sen slope (Sen 1968), using both $-5^{\circ} \mathrm{C}$ and $-2{ }^{\circ} \mathrm{C}$ minimum temperature thresholds (Steiger and Mayer 2008, Wilson et al. 2018).

In addition to the original snow-covered days (SWE $>0 \mathrm{~mm}$ ) metric commonly used in the peer-reviewed literature (Burakowski et al. 2008, Contosta et al. 2019, Hayhoe et al. 2007), we added a second snow-covered days threshold of SWE > $30 \mathrm{~mm}$, which is $\sim 15 \mathrm{~cm}$ (6 in) physical snow height, assuming a snow density of $200 \mathrm{~kg} / \mathrm{m}^{-3}$ as a proxy for deeper, settled, and compacted snow cover. Operationally, the value of this snow depth threshold varies from $15-30 \mathrm{~cm}$ for winter recreation activities such as Nordic and alpine skiing, respectively (Hennessey et al. 2008; Morin et al. 2021; Scott et al. 2008, 2015 and references within) to as much as 120 $\mathrm{cm}$ for buffering soils from atmospheric fluctuations in temperature (Decker et al. 2003, Hardy et al. 2001, Liptzin et al. 2009, Sanders-DeMott et al. 2018, Sorensen et al. 2018, Tatariw et al. 2017, Templer et al. 2012); thus, the 30-mm SWE threshold we chose represents a minimum for deep snow cover.

We also calculated "bare ground thaw days/mud days", which is an indicator representative of conditions when temperatures are above freezing and snow cover is absent (Contosta et al. 2019). Here, we eliminated the use of "frozen ground days" ( $\mathrm{SWE}=0 \mathrm{~mm}$ and maximum temperature $<0{ }^{\circ} \mathrm{C}$ ) used in Contosta et al. (2019), due to the low frequency of their occurrence across the region in both the historical and future simulations.

\section{Statistical approach}

For regionally averaged climatology and winter climate indicators, we assessed statistical significance using the Welsh's $t$-test of the null hypotheses to test the following: (1) the historical model ensemble mean is from the same population as the early, mid-, and late-century climatological ensemble means, and (2) the loweremissions climate scenario (RCP4.5) climatological means are from the same population as the higher-emissions climate scenario (RCP8.5) climatological means for early, mid-, and late century. We rejected the null hypothesis at $P<0.01$, indicating that the respective sample means are from 2 different populations. We also assessed statistical significance at the model grid-cell level using Welsh's $t$ test. We used the Benjamini-Hochberg procedure (Benjamini and Hochberg 1995) to reduce Type I errors (i.e., false positives) by ranking $P$-values from the original Welsh's $t$-test, assuming a false discovery rate of $5 \%$. We determined decadal rates of change over historical (1980-2005) and future (2006-2099) time slices using the nonparametric Sen slope (Sen 1968) and assessed two-sided statistical significance using the Mann-Kendall test (Mann 1945). 


\section{Results}

\section{Temperature}

The cold-season minimum and maximum temperature time series averaged over the study area, 1980-2099, is shown in Figure 1. Over the recent historical period (1980-2005), no statistically significant Sen slopes $(P<0.01)$ in minimum or maximum temperature were identified in the Livneh et al. (2013) gridded-observation dataset, and only 1 model in the minimum temperature LOCA ensemble had a statistically significant warming trend. These results are not surprising given the relatively short period of record (25 years). In general, however, the models perform well at capturing the span of historical climatology values in the gridded observations (Fig. 1).

Over the longer horizon, including the future projections (1980-2099), all 29 models exhibit statistically significant $(P<0.01)$ warming trends in both maximum and minimum temperature under the lower-emissions scenario (RCP4.5) and are doubled under higher (RCP8.5) emissions (see Figs. S1, S2 in Supplemental File 1, available online at http://www.eaglehill.us/NENAonline/ suppl-files/n28-sp11N1872j-Burakowski-s1, or for BioOne subscribers, at https:dx.doi.org/10.1656/ N1872j.s1). Monthly analysis of the future minimum temperature warming trends reveals that the greatest rates of cold-season warming are projected to occur during the meteorological winter months of December, January, and February (see Fig. S1 in Supplemental File 1). All 30-year ensemble means for early, mid- and latecentury under both scenarios are significantly warmer from the historical record at $P<0.01$, and the 30-year ensemble means for RCP8.5 mid- and late-century are significantly warmer than respective RCP4.5 scenario ensemble means (Table 1). The greatest seasonal changes occur in winter minimum temperature and precipitation (see Table S1 in Supplemental File 1). More southerly, lower elevation, and coastal regions are the first areas to cross the threshold from below-freezing average minimum temperature to above-freezing average minimum temperature (Fig. 2). By the end of the century, nearly all of the northeastern United states and southern Quebec will experience above-freezing average maximum temperatures under the higher emissions climate scenario (see Fig. S3 in Supplemental File 1).

Historically, the number of ice days (daily maximum temperature $<0{ }^{\circ} \mathrm{C}$ ) per cold season (Novmber-May) varies from less than a week in the southeasternmost part of the region to upwards of 4 months at higher elevations and in the northernmost extent of the study area (Fig. 3). Under the lower-emissions scenario, the models project significant declines in ice days in early, mid-, and late century relative to the historical baseline, for a total loss of 2 weeks by late century when averaged across the region. Under the higher-emissions RCP8.5 scenario, by the late century, the region averages just over 3 weeks of ice days, less than half of the historical baseline (Table 1).

For thaw days (daily maximum temperature $>0{ }^{\circ} \mathrm{C}$ ), few locations in the study area currently experience a fully below-freezing dormant season (November-May). During the recent historical period (1980-2005), most of the region experienced maximum daytime temperatures above freezing $\left(>0{ }^{\circ} \mathrm{C}\right)$ for most of the dormant 


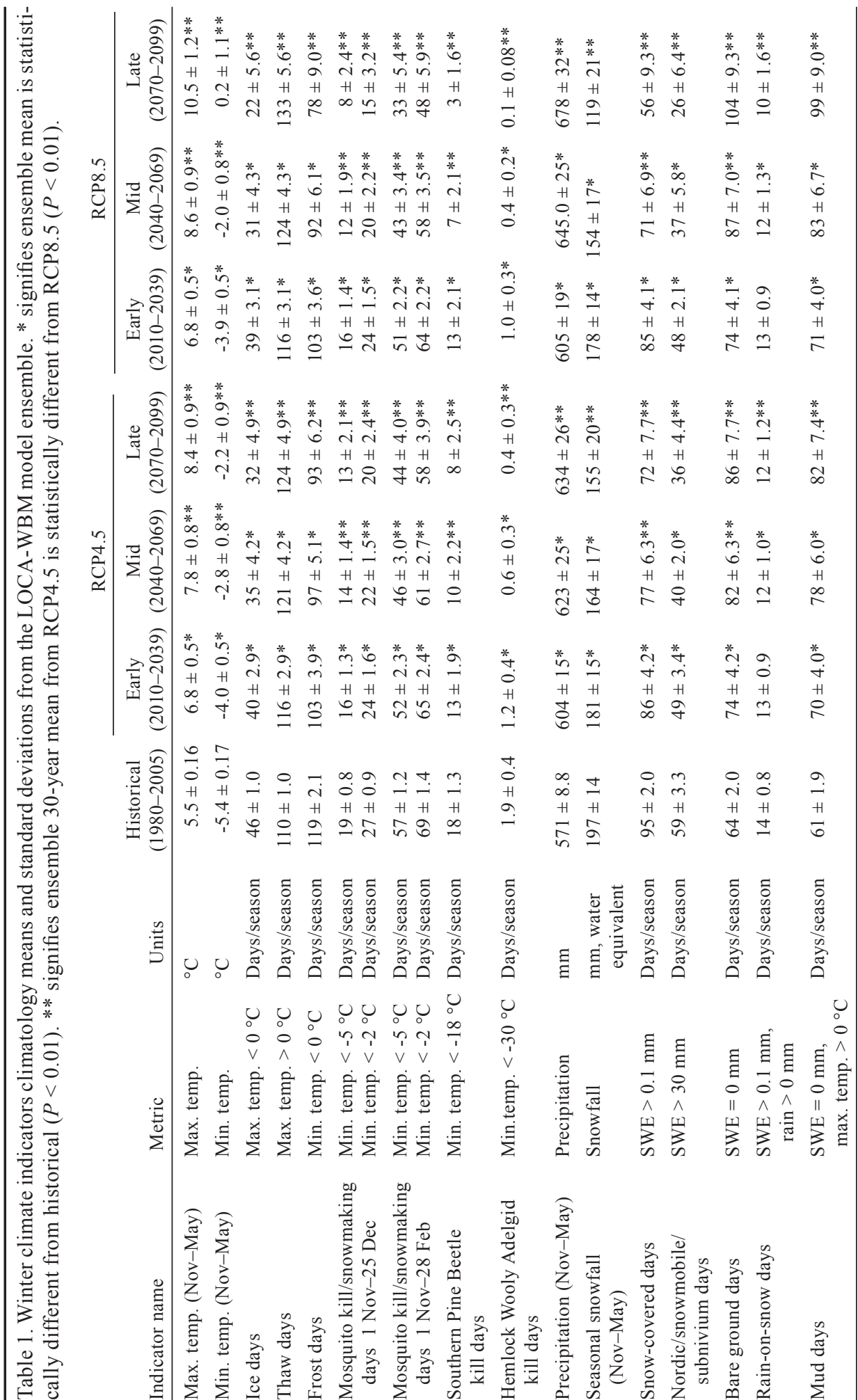


season (see Figs. S4, S8 in Supplemental File 1). By the end of the century (2070-2099), thaw days significantly increased under the lower-emissions scenario (RCP4.5) from a historical ensemble mean of $110 \pm 1$ days/season to $124 \pm 5$ days/ season (Table 1). Under the higher-emissions scenario (RCP8.5), more than half of Pennsylvania, nearly all of Connecticut, and the entire states of New Jersey and Rhode Island transition to a regime with nearly all days reaching above freezing (see Fig. S4 in Supplemental File 1).

Historically, the study area averaged $119 \pm 2$ Frost Days (daily minimum temperature $<0{ }^{\circ} \mathrm{C}$ ) between November and May (Table 1). By the end of the century

Figure 2. Cold-season (1 November-31 May) minimum temperature climatology for historical (top), early (2010-2039), mid- (2040-2069), and late (2070-2099) century. Left column is lower-emissions scenario (RCP4.5); right column is higher-emissions scenario (RCP8.5). Blue colors indicate below freezing, red colors indicate above freezing. Stippling indicates where future time slice mean is statistically significant from historical (19802099), $P<0.01$ (adjusted for false discovery rate of $5 \%$ using BenjaminiHochberg method).

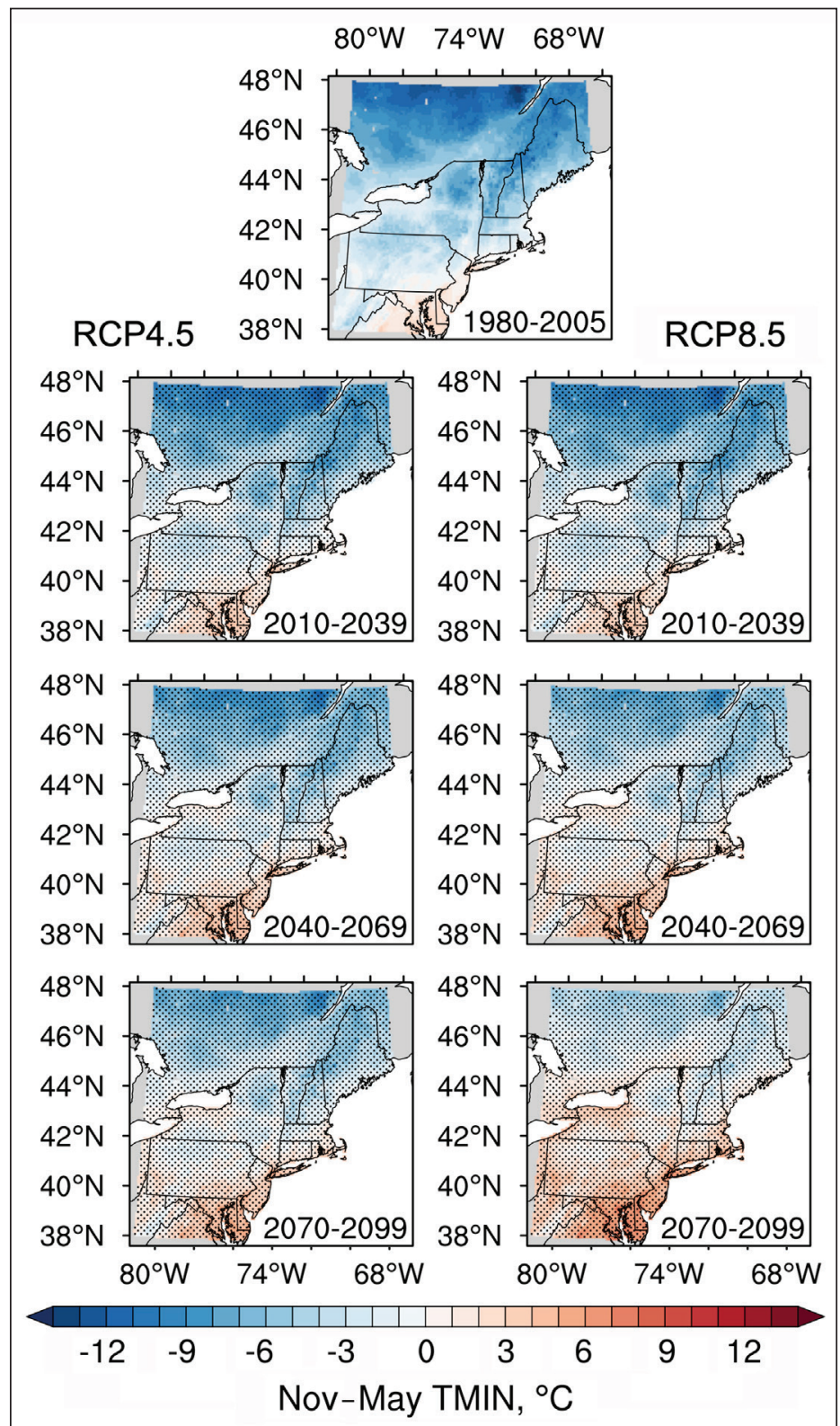


(2070-2099), frost days decline by over 3 weeks to $93 \pm 6$ days under the loweremissions scenario and by 6 weeks to $78 \pm 9$ days under higher emissions. For the southern part of the region, the reduction in frost days suggests a regime shift from frequent expectation of below-freezing temperatures to very infrequent belowfreezing temperatures (see Fig. S5 in Supplemental File 1).

Over the period 1980-2005, the region averaged $57 \pm 1$ mosquito kill/snowmaking days (daily minimum temperature $<-5{ }^{\circ} \mathrm{C}$ ) between 1 November and 28 February, varying from fewer than 10 days in the southernmost part of the region to over 100 days in the northernmost parts of southeast Canada (Table 1; see also Fig. S6 in Supplemental File 1). By mid-century (2040-2069), the projected number of

Figure 3. Cold-season (1 November-31 May) ice days (maximum temperature $\left.<0{ }^{\circ} \mathrm{C}\right)$ climatology for historical (top), early (2010-2039), mid(2040-2069), and late (2070-2099) century. Columns and stippling are as indicated in Figure 2.

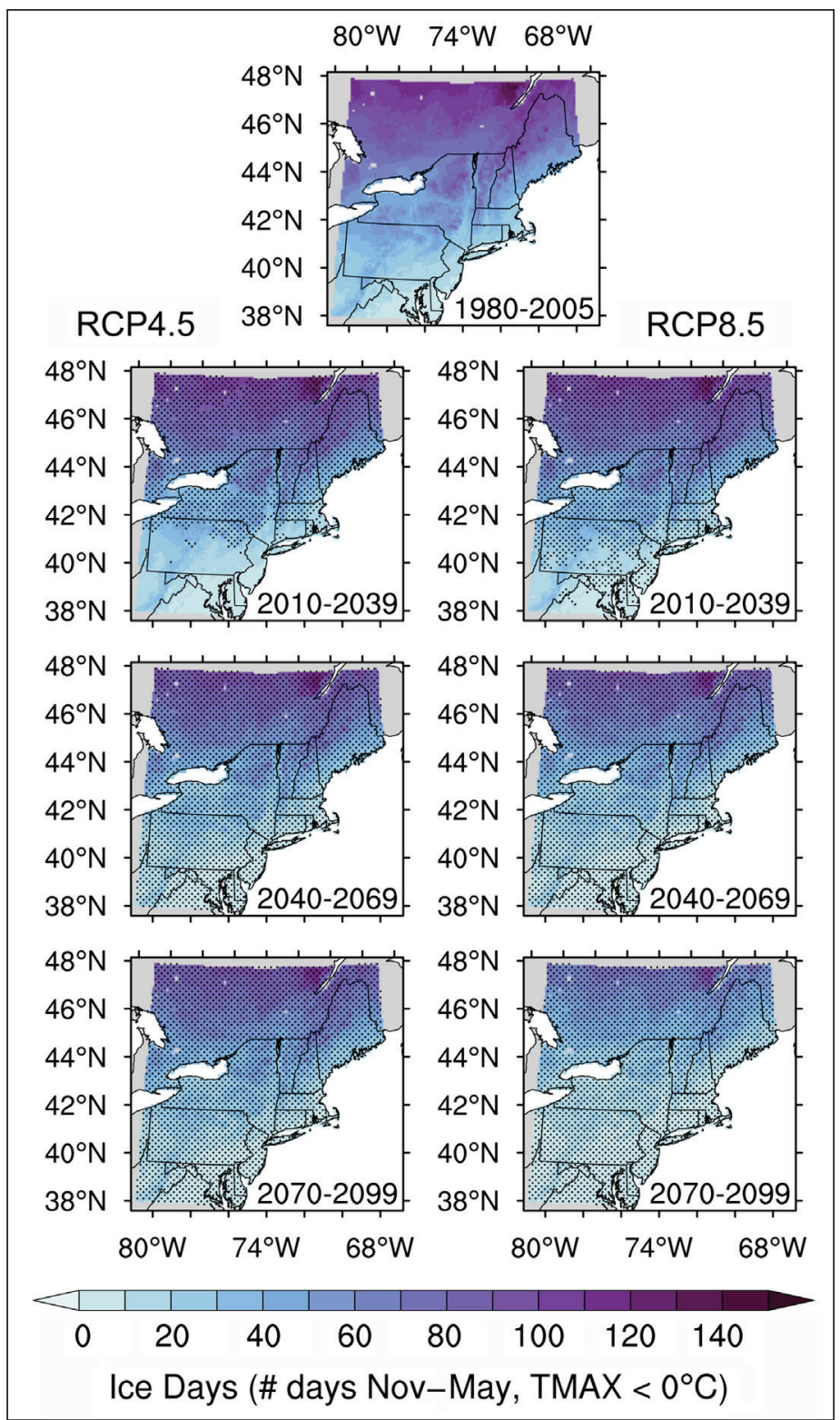


mosquito kill/snowmaking days are significantly higher under the lower-emissions scenario compared to the higher-emissions scenario. When considered through an outdoor-recreation lens, most ski resorts within the region are projected to experience a $20-50 \%$ reduction in the number of snowmaking days (minimum temperature $<-5{ }^{\circ} \mathrm{C}$ ) in the early part of the season (1 November- 25 December) under a lower-emissions scenario. The reductions were far greater under higher emissions: a $45-83 \%$ decrease in snowmaking days for the early winter ski season leading up to the Christmas holiday (Fig. 4). At most higher-elevation resorts in New York, Vermont, New Hampshire, and Maine, reductions in the snowmaking season through 28 February vary from $10 \%$ to $30 \%$ under lower emissions, with reductions of $20 \%$ to $50 \%$ under higher emissions. Recent technological advancements, however, have enabled snowmaking to occur at warmer temperatures, elevating the minimum temperature threshold from $-5{ }^{\circ} \mathrm{C}$ to $-2{ }^{\circ} \mathrm{C}$ (Scott et al. 2003). This -2 ${ }^{\circ} \mathrm{C}$ minimum temperature threshold would have lengthened the November through February snowmaking season by almost 2 weeks over the historical period, compared to the $-5{ }^{\circ} \mathrm{C}$ threshold (Table 1). By the end of the century, with the $-2{ }^{\circ} \mathrm{C}$ threshold, the study region averages nearly 2 months of snowmaking days under the lower-emissions scenario and $<50$ days under higher emissions (RCP8.5).

Warmer conditions during the dormant season may expand suitable habitat for forest insect pests. From the LOCA historical ensemble, the current range of

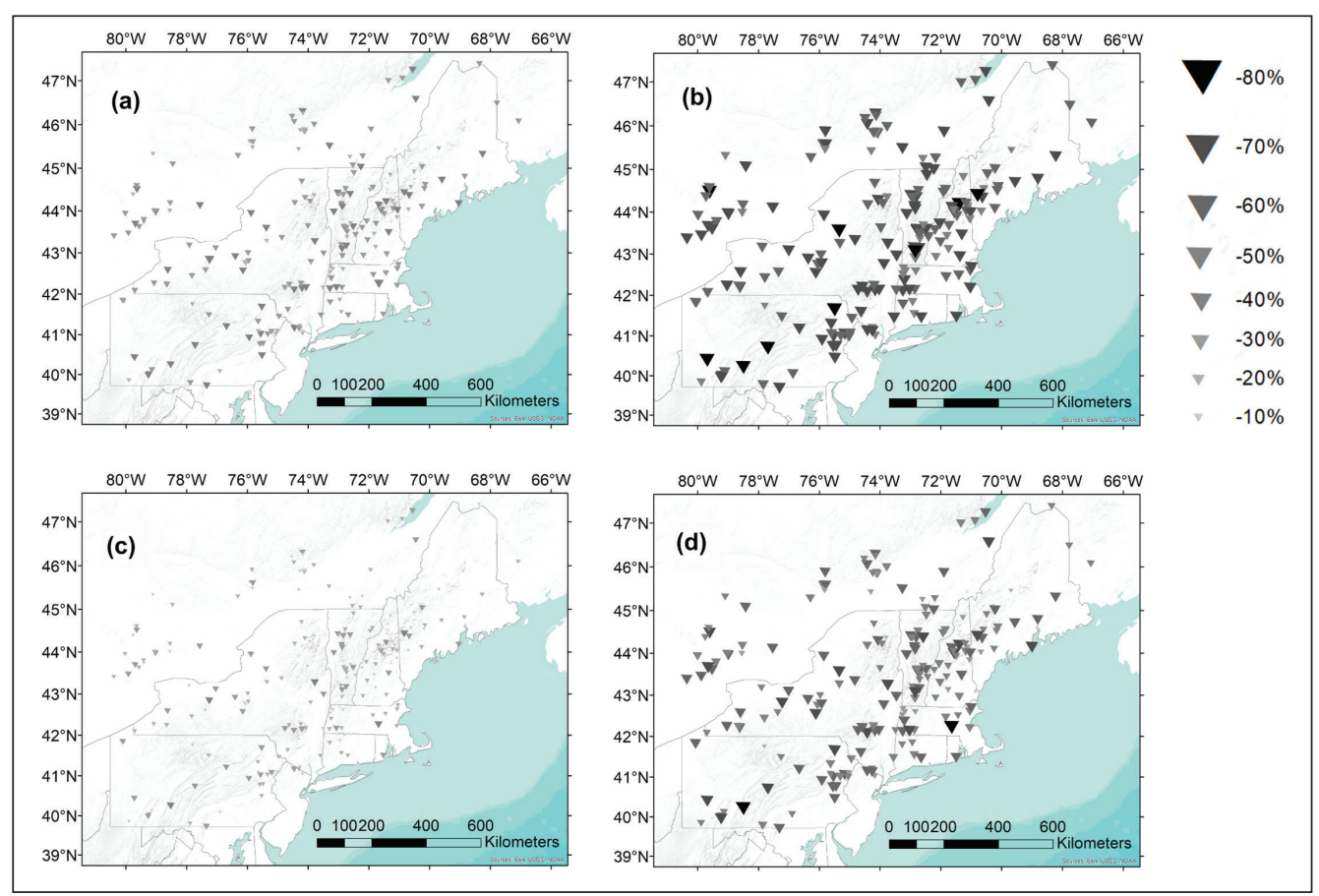

Figure 4. Percentage change in snowmaking days (minimum temperature $<-5^{\circ} \mathrm{C}$ ), $2006-$ 2099, for 1 November-25 December under (a) RCP4.5 and (b) RCP8.5, and for November 1 through February 28 under (c) RCP4.5 and (d) RCP8.5. Percentage change estimated from Sen slope, 2006-2099, relative to historical baseline (1980-2005). 
Southern Pine Beetle is captured moderately well compared to documented sightings that extend close to the northern border of Massachusetts with New Hampshire and Vermont (Dodds et al. 2018). Historically, the study region averages less than 3 weeks of Pine Beetle kill days (Table 1), with fewer than 10 Pine Beetle kill days in the southern and coastal regions (see Fig. S7 in Supplemental File 1). By mid- and late century, projections indicate fewer than 10 Pine Beetle kill days regionally and significantly fewer days in the higher- versus lower-emissions scenarios (Table 1). Additionally, there were few days historically that met the $-30{ }^{\circ} \mathrm{C}$ threshold for HWA kill days. All future projections indicated significant declines in the number of days with temperatures below $-30{ }^{\circ} \mathrm{C}$, with less than 1 day below this threshold in the mid- and late-century periods (Table 1).

\section{Precipitation}

Cold-season (November-May) precipitation was $571 \pm 8.8 \mathrm{~mm}$ during the historical period and is projected to increase significantly to $634 \pm 26 \mathrm{~mm}$ under the lower-emissions scenario (RCP4.5) and to $678 \pm 32 \mathrm{~mm}$ under higher emissions (RCP8.5) for the late-century projections (Fig. 5, Table 1). The largest increases in precipitation occur in meteorological winter (December-February), followed by

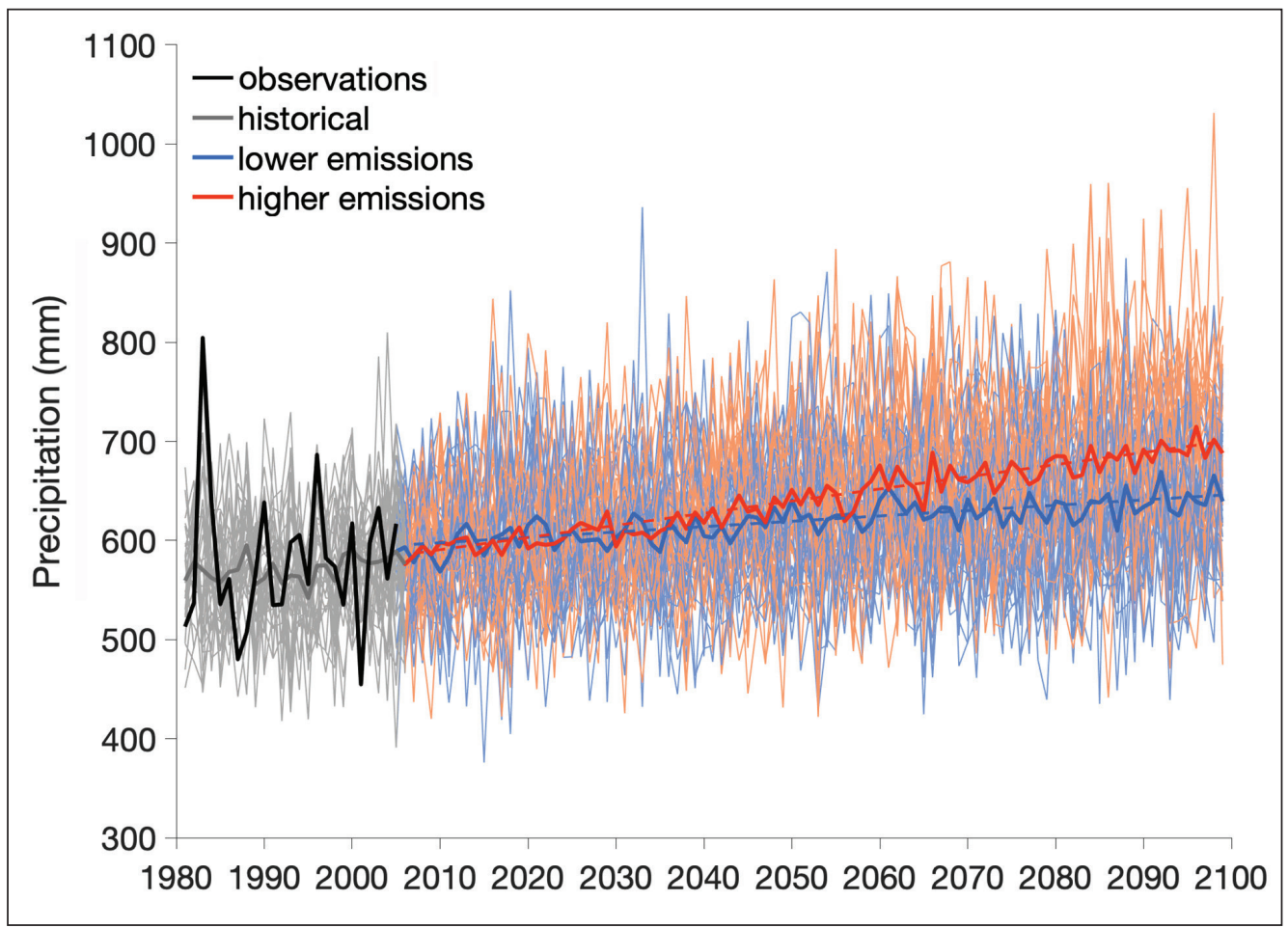

Figure 5. (a) Cold-season (November-May) precipitation, 1980-2099. The thin lines represent individual model runs and thick lines are the LOCA model ensemble mean. Grey lines are historical scenario (1980-2005), blue lines are lower-emissions scenario (RCP4.5), red lines are higher-emissions scenario (RCP8.5), and black line shows observations (Livneh et al. 2013). Dashed lines are Sen's slope for the ensemble mean, $P<0.01$. 
meteorological spring (March-May) (Table S1). No significant changes in summer (June-August) or fall (September-November) precipitation were detected (see Table S1 in Supplemental File 1), nor were the higher- (RCP8.5) and lower-emissions (RCP4.5) scenarios significantly different.

The study region averaged $\sim 200 \mathrm{~mm}$ w.e. (water equivalent) of snowfall during the cold season (November-May) over the historical period (Fig. 6, Table 1), which is equivalent to $\sim 200 \mathrm{~cm}$ ( $\sim 79$ in) of snowfall, assuming a fallen snow density of $10 \%$, or $\sim 100 \mathrm{~cm}$ ( $\sim 39$ in) of snowfall, assuming $20 \%$ snow density. Snowfall declines steadily and significantly through the 3 time periods we assessed in the $21^{\text {st }}$ century, and by 2100 , snowfall declines $\sim 22 \%$ and $\sim 40 \%$ of the historical amount for lower- and higher-emissions scenarios, respectively (Table 1).

\section{Snowpack}

Historically, the number of snow-covered days (SWE $>0 \mathrm{~mm}$ ) varies from $<20$ days in Delaware and Maryland to $>180$ days in the White Mountains (NH), Adirondacks (NY), and northern Appalachians in Maine (see Fig. S8 in Supplemental File 1). Region-wide, the number of days with snow cover decreases from $95 \pm 2$ days/season over the historical period (1980-2005) to $72 \pm 8$ days under the lower-emissions scenario (RCP4.5) and $56 \pm 9$ days under higher-emissions (RCP8.5) for the late-century projections, translating to losses of 1-2 months of snow cover (Table 1). The spatial distribution in historical and future snow-covered days closely mirrors the number of thaw days (see Fig. S4 in Supplemental File 1). Whereas states like New Jersey, Rhode Island, and Connecticut could historically expect to see 20-80 days of snow cover per season (November-May), they are

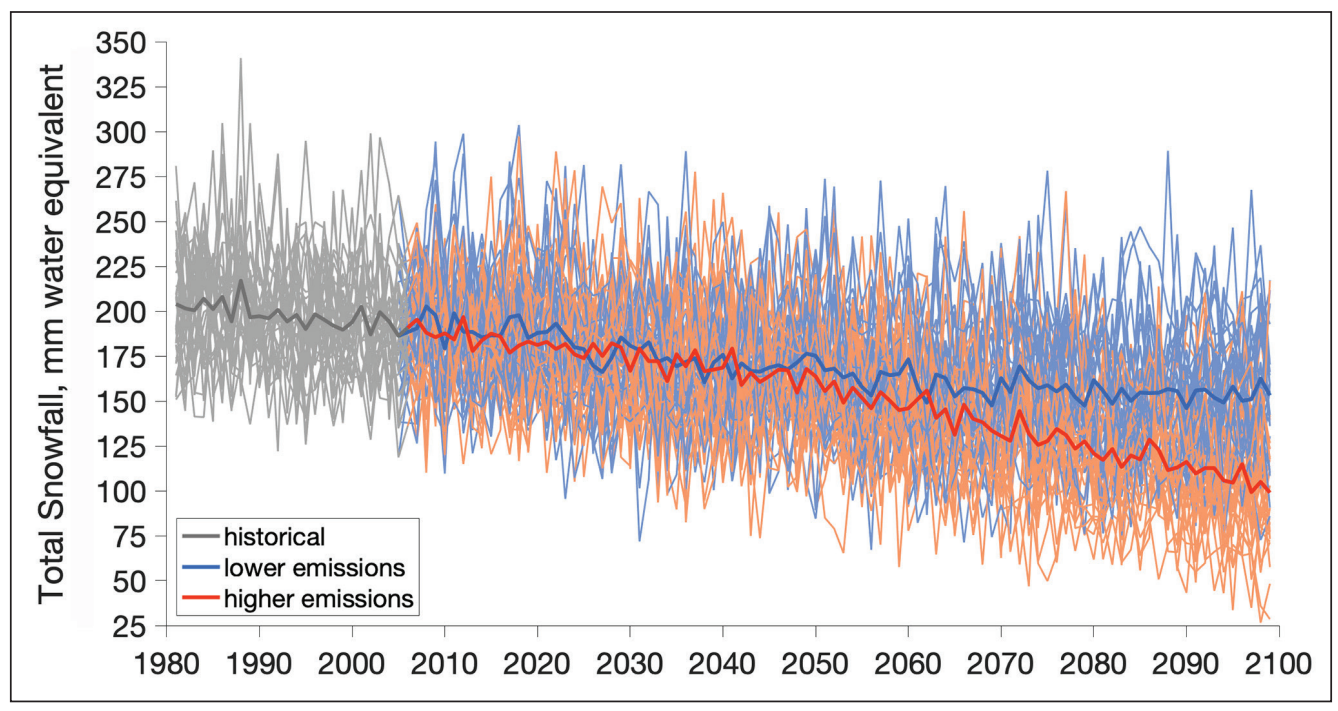

Figure 6. (a) Cold-season (November-May) snowfall (mm, water equivalent), 1980-2099. The thin lines represent individual model runs, and thick lines are the LOCA model ensemble mean. Grey lines are historical scenario (1980-2005), blue lines are lower-emissions scenario (RCP4.5), red lines are higher-emissions scenario (RCP8.5). Gridded observations of snowfall were not available in (Livneh et al. 2013). 
much more likely to have a snow-free winter by the end of the century under the higher-emissions scenario (see Fig. S8 in Supplemental File 1).

For the Nordic/snowmobile/subnivium snow-covered day threshold for deeper snowpack (SWE $>30 \mathrm{~mm}$ ), the region supported nearly 2 months of deep snowpack over the historical 1985-2005 period (Table 1), with upwards of 5 months at higher elevations and northerly locations (Fig. 7). By the end of the century, the duration of deep snowpack is projected to decline by 3 weeks under the loweremissions scenario. Under higher emissions, deep snowpack persists for less than a month (Table 1) when averaged across the region. Southern coastal locations are

Figure 7. Cold-season (November-May) snowcovered Days (SWE > 30 $\mathrm{mm})$ for historical (19812005), early (2010-2039), mid- (2040-2069), and late (2070-2099) century. Columns and stippling are as indicated in Figure 2.

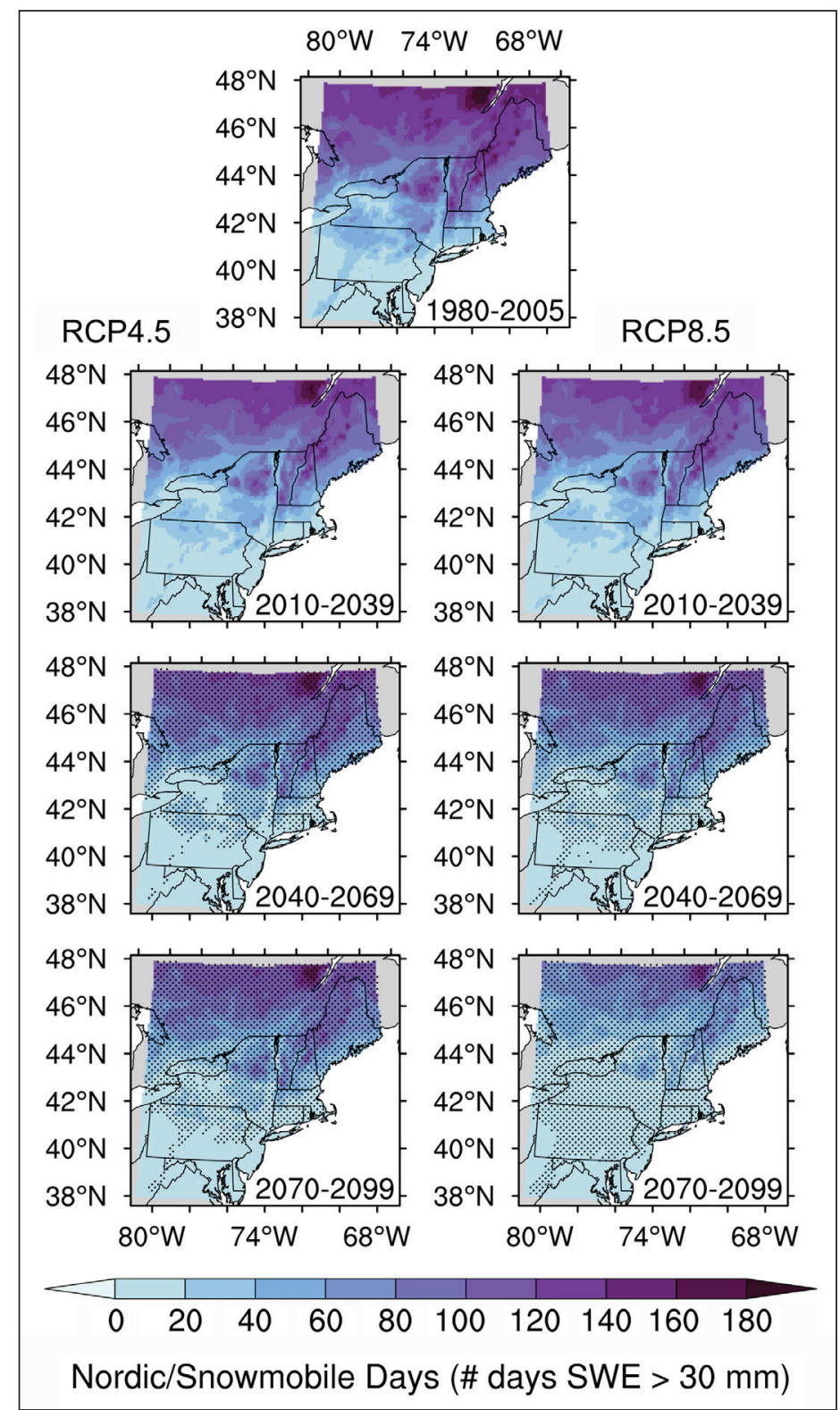


increasingly unlikely to maintain deep snowpacks, while northern, high-elevation locations remain more resilient to deep snowpack loss. As the number of days with snow cover decreases, there is a commensurate increase in the number of bareground days (Table 1).

Bare-ground thaw days, or mud days, occur when daily maximum temperature is above freezing and snow cover is absent. Across the entire region, the number of mud days significantly increases from $61 \pm 2$ days per season during the historical period to $82 \pm 7$ days per season in the lower-emissions scenario and $99 \pm 9$ days per season, or by nearly 1 month, in the higher-emissions scenario by the end of the century (Table 1). The increases are consistent with the positive trends in bareground days reported here, as there were few occurrences of frozen-ground days when SWE $=0$ and daily maximum temperature was $<0{ }^{\circ} \mathrm{C}$.

The potential impacts of more frequent mud days vary depending on when they occur within the cold season. By the end of the century, the models project that during meteorological winter (December-February), bare-ground/mud days double from about 9 days during the historical period to 18 days under the lower-emissions RCP4.5 scenario, and triple to 27 days under the higher-emissions RCP8.5 scenario (Fig. 8).

\section{Discussion}

The warming trends in the LOCA ensemble for the period 1980-2099 under the lower-emissions climate scenario (RCP4.5; see Figs. S1, S2 in Supplemental File 1) are on par with winter (December-March) rates of warming ( $\Delta$ minimum temperature $=0.42{ }^{\circ} \mathrm{C} /$ decade and $\Delta$ maximum temperature $=0.46{ }^{\circ} \mathrm{C} /$ decade )

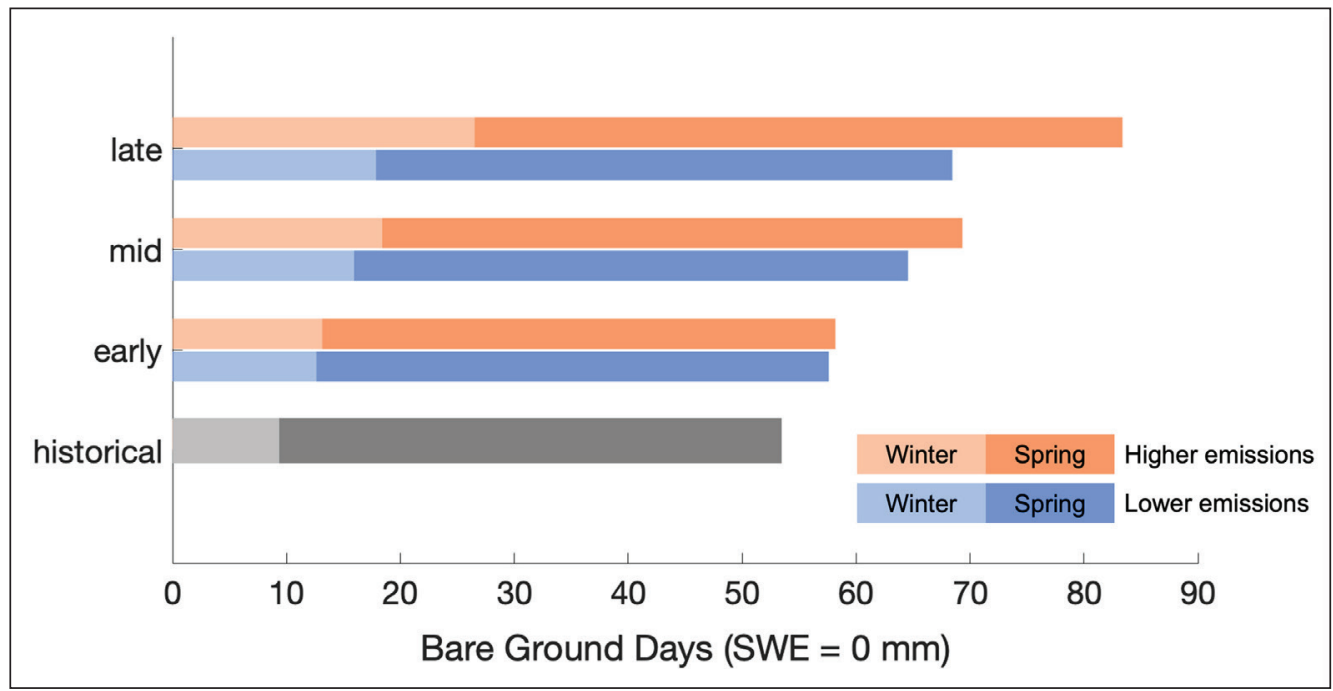

Figure 8. Increase in cool-season (November-May) bare-ground days ( $\mathrm{SWE}=0 \mathrm{~mm}$ ) relative to the historical period (grey), lower emissions (RCP4.5; blue), and higher emissions (RCP8.5; red) for early (2010-2039), mid- (2040-2069), and late (2070-2099) century. Lighter color bars indicate meteorological winter (December-February); darker color bars indicate spring (March through May). 
across the northeastern United States over the period 1965-2005 (Burakowski et al. 2008). Under the higher-emissions scenario (RCP8.5), however, warming trends are nearly double the rates of warming of the lower-emissions climate scenario. Projected end-of-century warming in the LOCA ensemble varies from 5.2 to $6.7^{\circ} \mathrm{C}$ for winter (December-February) maximum and minimum temperature (see Table $\mathrm{S} 1$ in Supplemental File 1); this finding is consistent with the mean meteorological winter temperature warming $\left(5.4{ }^{\circ} \mathrm{C}\right)$ arrived at previously in a 9-member CMIP4 model ensemble by Hayhoe et al. (2007), using a historical baseline of 1961-1990 (rather than the 1980-2005 historical baseline used here) and with considerably coarser model resolution, varying from $1.4^{\circ}$ to $5^{\circ}$ (compared to $1 / 16^{\circ}$ used here). More recent studies, also using a relatively coarse spatial resolution CMIP5 model ensemble, similarly report winter as the fastest warming season, both historically and in future projections (Karmalkar and Bradley 2017, Lynch et al. 2016). Additionally, the loss of ice days (daily maximum temperature $<0{ }^{\circ} \mathrm{C}$ ) reported here is in broad agreement with Rawlins et al. (2016), who mapped a broad swath of the mid-Atlantic region subject to complete loss of "freezing days" (defined as number of days with mean daily temperature $<0{ }^{\circ} \mathrm{C}$ ) by $2040-2070$ under the SRES A2 scenario relative to a $1971-2000$ baseline in coarser $0.5^{\circ}$ regional climate models in the North American Regional Climate Change Assessment Program (NARCCAP; Mearns et al. 2009) ensemble. This loss of ice days indicates the disappearance of a critical threshold - the freezing point of water-below which more recipitation falls as snow instead of rain; rivers, lakes, and streams remain frozen; and snowpacks persist to the following day with minimal melt.

When considered as the lower lethal temperature of invasive insect vectors such as Aedes albopictus (Skuse) (Asian Tiger Mosquito), the loss of mosquito kill days (daily minimum temperatures below $-5^{\circ} \mathrm{C}$ ) may carry human health consequences. Under both RCP4.5 and RCP8.5 scenarios, daily minimum temperatures below -5 ${ }^{\circ} \mathrm{C}$ are confined to more-northern and higher-elevation areas by the end-of-century, heralding the expansion of diseases, such as dengue and chikungunya fevers, eastern equine encephalitis, and West Nile virus (Ogden et al. 2014, Platonov et al. 2008, Rochlin et al. 2013). The spatial distribution of endemic Ixodes scapularis Say (Black-legged Tick) that carries the bacteria Borrelia burgdorferi Johnson et al. emend. Baranton et al., which causes Lyme disease, has also been linked to milder winters with reduced snow cover (Brownstein et al. 2003, Leighton et al. 2012, Levi et al. 2015).

In regard to winter recreation, high-elevation, northerly ski resorts retained adequate cold conditions for early season snowmaking under both emissions scenarios, compared to coastal, low-elevation resorts. This highlights both the importance and limits of snowmaking as an essential adaptation strategy for the ski industry. Murray et al. (2021 [this issue]) reported significant declines in frost days, ice days, and thaw days at Pinkham Notch (elevation $612 \mathrm{~m}$ a.s.1.) and the summit of Mount Washington (elevation $1917 \mathrm{~m}$ a.s.1.), illustrating consistent warming indicators across elevational gradients in the White Mountains of New Hampshire, where most of the larger ski resorts are located in the state. 
The changes in length of the snowmaking season documented here are more optimistic than the $80 \%$ to $100 \%$ reduction in season length in the northeastern United States reported in Wobus et al. (2017), which used a benchmark of 450 cumulative snowmaking hours with a wet bulb temperature below $-2.2{ }^{\circ} \mathrm{C}$ to initiate and sustain snowmaking through the snow season. As Scott et al. (2020) note, however, 450 hours is an excessively high benchmark and may not be representative of smaller regional markets, where the number of cumulative snowmaking hours can be as low as 72 hours before terrain is skiable.

Numerous studies have developed a suite of metrics related to the economic viability of resort skiing related to both natural snow conditions and conditions for snowmaking and maintaining a baselayer for snowpack (Abegg et al. 2020; Dawson et al. 2013; Hamilton et al. 2003, 2007; Scott et al. 2008). Nonetheless, even with advances in snowmaking technology to cover more terrain in less time using less energy at warmer temperatures, only 29 of the 197 ski areas in Québec and the northeastern US remain viable (i.e., >100-day season length and open for Christmas-New Year holiday) under the higher-emissions RCP8.5 scenario (Scott et al. 2020). These regional trends of large losses in snowmaking days in southern New England and at low elevations reported here are in broad agreement with the more sophisticated SkiSim snowmaking model-projected total season length, which accounts for critical technical snow-depth thresholds for base layers, snowpack density from compaction of trail grooming, degree-day factors for melting of natural and technical snow, and critical altitudes for ski-lift operation (Scott et al. 2003, 2020; Steiger 2010).

In regard to forest health, future projections suggest northward expansion of the destructive Southern Pine Beetle into Pinus resinosa Sol. ex Aiton (Red Pine), Pinus strobus L. (Eastern White Pine), and Pinus banksiana Lamb. (Jack Pine) habitat in northern New England and southeastern Canada, though high elevations may remain cold enough to keep Southern Pine Beetle populations from expanding (Dodds et al. 2018; see Fig. S7 in Supplemental File 1). Similar findings on northward expansion were reported by Lesk et al. (2017), though the coarse resolution of the GCMs was not sufficient to capture the colder high elevations. For Southern Pine Beetle kill days, the daily minimum threshold of $-18^{\circ} \mathrm{C}$ as an indicator of Pine Beetle kill is $2{ }^{\circ} \mathrm{C}$ colder than the documented lethal phloem temperature limit of $-16^{\circ} \mathrm{C}$ (Sømme 1982, Ungerer et al. 1999). Southern Pine Beetle have expanded $200 \mathrm{~km}$ northward in recent decades, from their native Pinus taeda L. (Loblolly Pine) and Pinus echinata Mill. (Shortleaf Pine) forest habitats in the southeastern United States to pine forests in the mid-Atlantic and southern New England (Dodds et al. 2018), threatening stands of globally rare Pinus rigida Mill. (Pitch Pine; Heuss et al. 2019). Southern Pine Beetles have also been recently detected in Red Pine, Eastern White Pine, and Jack Pine in New York (Lesk et al. 2017, NY Department of Environmental Conservation 2021).

Another destructive forest pest, the non-native HWA is susceptible to overwintering mortality when temperatures remain cold for long durations or during extreme cold snaps (Fitzpatrick et al. 2012, Gouli et al. 2000, Paradis et al. 2008, 
Parker et al. 1999, Shields and Cheah 2005, Skinner et al. 2003). It should be noted, however, that the literature defines 2 different thresholds for their mortality: mean winter temperature of $<-5^{\circ} \mathrm{C}$ (Paradis et al. 2008), and temperatures below $-30{ }^{\circ} \mathrm{C}$, which caused mortality in a laboratory study (Gouli et al. 2000). HWA arrived in Connecticut in the mid-1980s and has been slowly spreading northward into southern New Hampshire, Vermont, and coastal Maine (McClure 1990). Previous work by Paradis et al. (2008) evaluated expansion of HWA's range in New England using 7 different overwintering temperature metrics, finding a mean winter temperature of $<-5^{\circ} \mathrm{C}$ emerged as the best predictor. Using the $-5^{\circ} \mathrm{C}$ metric, Paradis et al. (2008) projected winter temperatures into the future using SRES scenarios (B1-lower, A1fi-higher) and found that HWA's range expands northward to the foothills of the White Mountains in New Hampshire, the Green Mountains in Vermont, and the Adirondacks in New York. Under the higher-emissions scenario, the range expands fully to most summits in New England and New York with few high-elevation exceptions; only the northernmost reaches of Maine and New Hampshire and the Northeast Kingdom in Vermont remain hostile environments for HWA. Despite the use of 2 different thresholds, $-5{ }^{\circ} \mathrm{C}$ in Paradis et al. (2008) and $-30{ }^{\circ} \mathrm{C}$ here, the model results of this study align with the expanded range determined by Paradis et al. (2008).

In regard to precipitation, Hayhoe et al. (2007) reported a 30\% projected increase in winter (December-February) precipitation by late century (2070-2099) under the A1 SRES higher-emissions scenario, compared to a $22 \%$ increase in winter precipitation under higher emissions (RCP8.5) reported here (Table S1). Similarly, Karmalkar and Bradley (2017) projected wetter winter conditions over the northeastern United States under higher emissions using a CMIP5 multimodel ensemble at $2.5^{\circ} \times 2.5^{\circ}$ grid spacing. Relative to the $1961-1990$ baseline, a 17 -member CMIP5 ensemble at $1.5^{\circ} \times 1.5^{\circ}$ grid spacing also produced a significant increase in winter precipitation over the northeastern United States and southeastern Canada (Maloney et al. 2014).

These future projections in precipitation contrast with historical trends reported here and elsewhere, which indicate that the largest changes in seasonal precipitation have historically occurred in summer and fall, with only modest increases in winter precipitation over the northeastern United States (Easterling et al. 2017). Ning and Bradley (2015) investigated changes in the rain-snow transition zone in the central and eastern United States and reported a $2^{\circ}$ latitude shift northward under the lower-emissions RCP4.5 scenario and a $4^{\circ}$ latitude shift northward under the higher-emissions RCP8.5 scenario. The projected seasonal shift in precipitation trends toward wetter winters is likely due to increases in water vapor at northern latitudes that are tied to expansion of Hadley cells (Easterling et al. 2017, Perlwitz et al. 2017). The projections of wetter winters, combined with warming temperatures, suggest future winters will be dominated by rain rather than snow precipitation, removing the influence of snowmelt on spring runoff (Grogan et al. 2020).

The model results indicate a significant loss of deep snowpacks ( $\mathrm{SWE}>30 \mathrm{~mm}$ ), from nearly 2 months of subnivium habitat during the historical period to $<1$ month 
by the end of the century, under the higher-emissions scenario (Table 1). Using the same dataset presented here, Grogan et al. (2020) reported loss of snow cover under the higher-emissions scenario across $59 \%$ of the study region, and subsequent loss of the spring freshet in the areas that lost snow cover, defined as greater than $30 \mathrm{~mm}$ SWE for at least 20 days per water year (October-September).

Deep snowpacks provide a thermally stable and sufficiently humid subnivean habitat for a variety of plants, animals, and microbes (Aitchison 2001, Pauli et al. 2013, Pruitt 1970, Thompson et al. 2021). Declines in snowpack depth can be detrimental to survival of cold-dependent wildlife. For example, Lynx canadensis Kerr (Canada Lynx), which have threatened status in the lower 48 US states, are unlikely to occur where annual snowfall is $<270 \mathrm{~cm} /$ year (Hoving et al. 2005). Even for the historical period, our findings suggest that Lynx habitat would be limited in the southerly part of the study region. Using an assumption of $10 \%$ snow density, our projections indicate that future snow conditions will be inhospitable to Lynx in all but the most northerly and high-elevation regions by the end of the century (see Fig. S8 in Supplemental File 1). Likewise, smaller vertebrates such as shrews, mice, and voles rely on the subnivium for visual and physical protection from predators, while others like Erethizon dorsatum L. (North American Porcupine) and Martes americana (Turton) (American Marten) benefit from the thermal insulation for their dens or competitive advantage over other species (Carroll 2007, Krohn et al. 1995, Milling et al. 2018).

Herbaceous roots and seeds also benefit from deep, low-density snowpacks because they are protected from soil freezing and desiccation. Many freeze-tolerant and freeze-resistant invertebrates (i.e., Collembola [springtails], Acari [mites and ticks], Coleoptera [beetles], Araneae [spiders], and Diptera [true flies]) benefit from stable temperatures in the subnivium, allowing them to remain active throughout the winter (Aitchison 2001, Merriam et al. 1983). In a warming climate, trophic interactions held together by deep snowpacks form complex food-web processes that may risk alteration on multiple fronts (Carroll 2007, Penczykowski et al. 2017).

Furthermore, a deeper snowpack also creates a warmer subnivium that promotes conditions amenable to microbial activity, soil nutrient cycling, and soil respiration (Groffman et al. 2006, Monson et al. 2005, Sommerfeld et al. 1993, Wang et al. 2013). Shallow, more-ephemeral snowpacks may result in colder soils (Groffman et al. 2001, Henry 2008) and freeze-thaw cycles that might lyse microbial cells, kill fine roots, disrupts soil aggregates, and ultimately may lead to soil carbon and nutrient losses (Campbell et al. 2014, Cleavitt et al. 2008, Comerford et al. 2013, Durán et al. 2014, Fuss et al. 2016, Patel et al. 2018).

As both snowfall and snowpacks decline, the combination of more frequent mid-winter mud days and elevated liquid precipitation can result in saturated soils that, in turn, alter soil nutrient cycling and hydrologic connectivity, particularly if saturated soils become refrozen (Shanley and Chalmers 1999, Tatariw et al. 2017). Beyond these natural system impacts, mid-winter freeze-thaw cycles can also disrupt transportation through rutting of paved roads and erosion of unpaved roads, increasing maintenance costs (Jackson and Puccinelli 2006, Kwiatkowski 
et al. 2020). Increased frequency of mud days during spring can also impact infrastructure, as spring road conditions lead to the posting of dirt roads and the implementation of weight restrictions, both of which have economic consequences (Daniel et al. 2018).

Mud days are also projected to become more frequent in spring (March-May; Fig. 8), which fits with past research documenting earlier spring onset, both historically and into the future (Grogan et al. 2020, Schwartz et al. 2006). When mud days occur before forest canopy leaf out (i.e., the vernal window period between snow melt and canopy closure), they may result in wetter soils, given the absence of evapotranspiration removing water from the system (Harpold and Molotch 2015). A warmer, moister period between winter and the growing season may result in greater ecosystem carbon and nutrient losses (Groffman et al. 2012, Sanders-DeMott et al. 2020), with implications that are poorly understood (Contosta et al. 2017).

\section{Conclusions}

The ecosystems and human communities of northeastern North America have long been adapted to winters with sustained cold temperatures and persistent snow. These conditions are changing, however, with marked decreases over the past 100 years in the number of days in which air temperatures remain below freezing (ice days), and the number of days in which air temperatures stay below important thresholds, such as $-5^{\circ} \mathrm{C}$, which has been the temperature necessary for snowmaking operations at ski resorts, and also for controlling the spread of the invasive Asian Tiger Mosquito, a vector for human diseases like eastern equine encephalitis and dengue fever (Contosta et al. 2019). This study calculated projections for a suite of winter climate indicators, including these examples, 100 years into the future, using both higher- and lower-emissions scenarios. In the higher-emissions RCP8.5 scenario, greenhouse gases from the burning of fossil fuels and land-cover change continue to warm the Earth, resulting in cold-season temperatures at least $5{ }^{\circ} \mathrm{C}$ warmer than the recent historical period (1980-2005). Under the lower-emissions RCP4.5 scenario, warming during the cold season is limited to $\sim 3{ }^{\circ} \mathrm{C}$. Winter continues to warm at a faster rate than other seasons, regardless of scenario.

The results show that the loss of cold and snow in northeastern North America will continue or accelerate, particularly in the southerly and coastal areas of the region, which could see near-total loss of snow and freezing temperatures. Emissions scenarios play a crucial role in the loss of winter conditions, indicating a potential doubling of the losses of cold days and snow cover under higher emissions as compared to lower emissions. These changes portend possible reorganization of social and ecological systems that have historically relied on cold, snowy winters for habitat, water resources, forest health, local economies, cultural practices, and human wellbeing. These results and the accompanying LOCA-WBM dataset provide specific, local projections for changing winter climate over the coming century and point to the urgency of continued adaptation efforts. 


\section{Acknowledgments}

This research was supported by the National Science Foundation (NSF) EPSCoR Ecosystems and Society Project (EPS-1101245), NSF Macrosystems Biology and Early NEON Science (\#1802726), NSF EPSCoR Track 4 (\#1832959, \#1832970), and the NSF EPSCoR INSPIRES Project (\#1920908). Additionally, we thank 3 anonymous reviewers and Manuscript Editor Thomas Maier for their comments. This research was conducted on N'dakinna, which is the unceded traditional ancestral homeland of the Abenaki, Pennacook, and Wabanaki Peoples past and present. We acknowledge and honor with gratitude the land and waterways and the alnobak (people) who have stewarded N'dakinna throughout the generations.

\section{Literature Cited}

Abatzoglou, J.T., and T.J. Brown. 2012. A comparison of statistical downscaling methods suited for wildfire applications. International Journal of Climatology 32(5):772-780. https://doi.org/10.1002/joc.2312.

Abegg, B., S. Morin, O.C. Demiroglu, H. François, M. Rothleitner, and U. Strasser. 2020. Overloaded! Critical revision and a new conceptual approach for snow indicators in ski tourism. International Journal of Biometeorology 65(Special Issue: Climate, Tourism, and Recreation):691-701. https://doi.org/10.1007/s00484-020-01867-3.

Aitchison, C.W. 2001. The effect of snow cover on small animals. Pp. 229-256, In H.G. Jones, J.W. Pomeroy, D.A. Walker, and R.W. Hoham (Eds.). Snow Ecology: An Interdisciplinary Examination of Snow-Covered Ecosystems. Cambridge University Press, Cambridge, UK. 400 pp.

Benjamini, Y., and Y. Hochberg. 1995. Controlling the false discovery rate: A practical and powerful approach to multiple testing. Journal of the Royal Statistical Society Series B 57:289-300. https://doi.org/10.1111/j.2517-6161.1995.tb02031.x.

Brownstein, J.S., T.R. Holford, and D. Fish. 2003. A climate-based model predicts the spatial distribution of the Lyme disease vector Ixodes scapularis in the United States. Environmental Health Perspectives 111:1152-1157. https://doi.org/10.1289/ehp.6052.

Burakowski, E.A., and M. Magnusson. 2012. Climate impacts on the winter tourism economy in the United States. Natural Resources Defense Council and Protect Our Winters, Washington, DC. 34 pp.

Burakowski, E.A., C.P. Wake, B. Braswell, and D.P. Brown. 2008. Trends in wintertime climate in the northeastern United States: 1965-2005. Journal of Geophysical Research Atmospheres 113: D20114. https://doi.org/10.1029/2008JD009870.

Campbell, J.L., A.M Socci, and P.H. Templer. 2014. Increased nitrogen leaching following soil freezing is due to decreased root uptake in a northern hardwood forest. Global Change Biology 20:2663-2673. https://doi.org/10.1111/gcb.12532.

Carroll, C. 2007. Interacting effects of climate change, landscape conversion, and harvest on carnivore populations at the range margin: Marten and Lynx in the northern Appalachians. Conservation Biology 21:1092-1104. https://doi.org/10.1111/j.15231739.2007.00719.x.

Casson, N., A. Contosta, E. Burakowski, J. L. Campbell, M. Crandall, I. Creed, C. Eimers, S. Garlick, D. Lutz, M. Morison, A. Morzillo, and S. Nelson. 2019. Winter weather whiplash: Impacts of meteorological events misaligned with natural and human systems in seasonally snow-covered regions. Earth's Future 7(12):1434-1450. https://doi. org/10.1029/2019EF001224. 
Cleavitt, N.L., T.J. Fahey, P.M. Groffman, J.P. Hardy, K.S. Henry, and C.T. Driscoll. 2008. Effects of soil freezing on fine roots in a northern hardwood forest. Canadian Journal of Forest Research 38:82-91.

Collins, M., R. Knutti, J. Arblaster, J.-L. Dufresne, T. Fichefet, P. Friedlingstein, X. Gao, W.J. Gutowski, T. Johns, G. Krinner, M. Shongwe, C. Tebaldi, A.J. Weaver and M. Wehner. 2013. Long-term climate change: Projections, commitments and irreversibility. In T.F. Stocker, D. Qin, G.-K. Plattner, M. Tignor, S.K. Allen, J. Boschung, A. Nauels, Y. Xia, V. Bex and P.M. Midgley (Eds.). Climate Change 2013: The Physical Science Basis. Contribution of Working Group 1 to the Fifth Assessment Report of the Intergovernmental Panel on Climate Change. Cambridge University Press, Cambridge, UK. 1535 pp.

Comerford, D.P., P.G. Schaberg, P.H. Templer, A.M. Socci, J.L. Campbell, and K.F. Wallin. 2013. Influence of experimental snow removal on root and canopy physiology of Sugar Maple trees in a northern hardwood forest. Oecologia 171:261-269. https://doi. org/10.1007/s00442-012-2393-x.

Contosta, A.R., A. Adolph, D. Burchsted, E.A Burakowski, M. Green, D. Guerra, M. Albert, J. Dibb, M. Martin, W.H. McDowell, M. Routhier, C.P. Wake, R, Whitaker, and W. Wollheim. 2017. A longer vernal window: The role of winter coldness and snowpack in driving spring transitions and lags. Global Change Biology 23:1610-1625. https://doi. org/10.1111/gcb.13517.

Contosta, A., N. Casson, S. Garlick, S. Nelson, M. Ayres, E.A. Burakowski, J.L Campbell, I. Creed, et al. 2019. Northern forest winters have lost cold, snowy conditions that are important for ecosystems and human communities. Ecological Applications 29(7):e01974. https://doi.org/10.1002/eap.1974.

Contosta, A., N.J. Casson, S.J. Nelson, and S.G. Garlick. 2020. Defining frigid winter illuminates its loss across seasonally snow-covered areas of eastern North America. Environmental Research Letters 15(3):034020. https://doi.org/10.1088/1748-9326/ab54f3.

Daniel, J. S., J.M. Jacobs, H. Miller, A. Stoner, J. Crowley, M. Khalkhali, and A. Thomas. 2018. Climate change: Potential impacts on frost-thaw conditions and seasonal load restriction timing for low-volume roadways. Road Materials and Pavement Design 19(5):1126-1146. https://doi.org/10.1080/14680629.2017.1302355.

Dawson, J., D. Scott, and M. Havitz. 2013. Skier demand and behavioural adaptation to climate change in the US Northeast. Leisure 37(2):127-143. https://doi.org/10.1080/14 927713.2013.805037.

Decker, K.L.M., D. Wang, C. Waite, and T. Scherbatskoy. 2003. Snow removal and ambient air temperature effects on forest soil temperatures in Northern Vermont. Soil Science Society American Journal 67:1234-1242.

Dodds, K.J., C.F. Aoki, A. Arango-Velez, J. Cancelliere, A.W. D’Amato, M.F. DiGirolomo, and R.J. Rabaglia. 2018. Expansion of Southern Pine Beetle into northeastern Forests: Management and impact of a primary bark beetle in a new region. Journal of Forestry 116(2):178-191. https://doi.org/10.1093/jofore/fvx009.

Donat, M.G., L.V. Alexander, H. Yang, I. Durre, R. Vose, R.J.H. Dunn, K.M. Willett, E. Aguilar, M. Brunet, J. Caesar, and B. Hewitson. 2013. Updated analyses of temperature and precipitation extreme indices since the beginning of the twentieth century: The HadEX2 dataset. Journal of Geophysical Research Atmospheres 118(5):2098-2118. https://doi.org/10.1002/jgrd.50150.

Dukes, J.S., J. Pontius, D. Orwi, J.R. Garnas, V.L. Rodgers, N. Brazee, B. Cooke, K.A. Theoharides, et al. 2009. Responses of insect pests, pathogens, and invasive plant species to climate change in the forests of northeastern North America: What can we predict? Canadian Journal of Forest Research 39:231-248. https://doi.org/10.1139/X08-171. 
Dupigny-Giroux, L.A., E.L. Mecray, M.D. Lemcke-Stampone, G.A. Hodgkins, E.E. Lentz, K.E. Mills, E.D. Lane, R. Miller, D.Y. Hollinger, W.D. Solecki, G.A. Wellenius, P.E. Sheffield, A.B. MacDonald, and C. Caldwell. 2018. Northeast. Pp. 669-742. In D.R. Reidmiller, C.W. Avery, D.R. Easterling, K.E. Kunkel, K.L.M. Lewis, T.K. Maycock, and B.C. Stewart (Eds.). Impacts, Risks, and Adaptation in the United States: Fourth National Climate Assessment, Volume II. US Global Change Research Program, Washington, DC. 1526 pp. https://doi.org/10.7930/NCA4.2018.CH18.

Durán, J., J.L. Morse, P.M. Groffman, J.L. Campbell, L.M. Christenson, C.T. Driscoll, T.J. Fahey, M.C. Fisk, M.J. Mitchell, and P.H. Templer. 2014. Winter climate change affects growing-season soil microbial biomass and activity in northern hardwood forests. Global Change Biology 20:3568-3577. https://doi.org/10.1111/gcb.12624.

Easterling, D.R., K.E. Kunkel, J.R. Arnold, T. Knutson, A.N. LeGrande, L.R. Leung, R.S. Vose, D.E. Waliser, and M.F. Wehner. 2017. Precipitation change in the United States. Pp 207-230, In D.J. Wuebbles, D.W. Fahey, K.A. Hibbard, D.J. Dokken, B.C. Stewart, and T.K. Maycock (Eds.). Climate Science Special Report: Fourth National Climate Assessment, Volume I. US Global Change Research Program, Washington, DC. 470 pp. https://doi.org/10.7930/J0H993CC.

Fitzpatrick, M.C., E.L. Preisser, A. Porter, J. Elkinton, and A.M. Ellison. 2012. Modeling range dynamics in heterogeneous landscapes: Invasion of the Hemlock Woolly Adelgid in eastern North America. Ecological Applications 22:472-486. https://doi. org/10.1890/11-0009.1.

Fuss, C.B., C.T. Driscoll, P.M. Groffman, J.L. Campbell, L.M. Christenson, T.J. Fahey, M.C. Fisk, M.J. Mitchell, P.H. Templer, J. Durán, and J.L. Morse. 2016. Nitrate and dissolved organic carbon mobilization in response to soil freezing variability. Biogeochemistry 131:35-47. https://doi.org/10.1007/s10533-016-0262-0.

Gouli, V., B.L. Parker, and M. Skinner. 2000. Haemocytes of the Hemlock Woolly Adelgid, Adelges tsugae Annand (Hom., Adelgidae), and changes after exposure to low temperatures. Journal of Applied Entomology 124:201-206.

Groffman, P.M., C.T. Driscoll, T. Fahey, J.P. Hardy, R. Fitzhugh, and G. Tierney. 2001. Colder soils in a warmer world: A snow-manipulation study in a northern hardwood forest ecosystem. Biogeochemistry 56:135-150.

Groffman, P.M., J.P. Hardy, C.T. Driscoll, and T.J. Fahey. 2006. Snow depth, soil freezing, and fluxes of carbon dioxide, nitrous oxide and methane in a northern hardwood forest. Global Change Biology 12:1748-1760.

Groffman P.M., L.E. Rustad, P.H. Templer, J.L. Campbell, L.M. Christenson, N.K. Lany, A. Socci, M.A. Vadeboncoeur, et al. 2012. Long-term integrated studies show complex and surprising effects of climate change in the northern hardwood forest. BioScience 62:1056-1066. https://doi.org/10.1525/bio.2012.62.12.7.

Grogan, D.S. 2016. Global and regional assessments of unsustainable groundwater use in irrigated agriculture. Ph.D. Dissertation. University of New Hampshire, Durham, NH. $223 \mathrm{pp}$. Available online at http://scholars.unh.edu/dissertation/2.

Grogan, D.S., E.A. Burakowski, and A.R. Contosta. 2020. Snowmelt control on spring hydrology declines as the vernal window lengthens. Environmental Research Letters 15(11): 114040 .

Hagenstad, M., E.A. Burakowski, and R. Hill. 2018. Economic contributions of the winter sports industry in a changing climate. Protect Our Winters, Boulder, CO. 70 pp.

Hamilton, L.C., D.E. Rohall, B.C. Brown, G.F. Hayward, and B.D. Keim. 2003. Warming winters and New Hampshire's lost ski areas: An integrated case study. International Journal of Sociology and Social Policy 23(10):52-73. 
Hamilton, L.C., C. Brown, and B.D. Keim. 2007. Ski areas, weather, and climate: Timeseries models for New England case studies. International Journal of Climatology 27:2113-2124. https://doi.org/10.1002/joc.1502.

Hardy, J.P., P.M. Groffman, R.D. Fitzhugh, K.S. Henry, A.T. Welman, J.D. Demers, T.J. Fahey, C.T. Driscoll, G.L. Tierney, and S. Nolan. 2001. Snow-depth manipulation and its influence on soil frost and water dynamics in a northern hardwood forest. Biogeochemistry 56:151-174. https://doi.org/10.1023/A:1013036803050.

Harpold, A.A., and N.P. Molotch. 2015. Sensitivity of soil-water availability to changing snowmelt timing in the western US. Geophysical Research Letters 42:8011-8020. https://doi.org/10.1002/2015GL065855.

Hayhoe, K., C.P. Wake, T.G. Huntington, L. Luo, M.D. Schwartz, J. Sheffield, E. Wood, B. Anderson, J. Bradbury, A. DeGaetano, T.J. Troy, and D. Wolfe. 2007. Past and future changes in climate and hydrological indicators in the US Northeast. Climate Dynamics 28:381-407. https://doi.org/10.1007/s00382-006-0187-8.

Hennessey, K.J., P.H. Whetton, K. Walsh, I.N. Smith, J.M. Bathols, M. Hutchinson, and J. Sharples. 2008. Climate-change effects on snow conditions in mainland Australia and adaptation at ski resorts through snowmaking. Climate Research 35(3):255-270.

Henry, H.A.L. 2008. Climate change and soil freezing dynamics: Historical trends and projected changes. Climatic Change 87:421-434. https://doi.org/10.1007/s10584-0079322-8.

Heuss, M., A.W. D'Amato, and K.J. Dodds. 2019. Northward expansion of Southern Pine Beetle generates significant alterations to forest structure and composition of globally rare Pinus rigida forests. Forest Ecology and Management 434:119-130. https://doi. org/10.1016/j.foreco.2018.12.015.

Hidalgo, H.G., M.D. Dettinger, and D.R. Cayan. 2008. Downscaling with constructed analogues: Daily precipitation and temperature fields over the United States. CEC PIER Project Rep. CEC-500-2007-123. 48 pp. Available online at http://repositorio.ucr.ac.cr/ bitstream/handle/10669/29838/CEC-500-2007-123.PDF? sequence=1\&isAllowed $=\mathrm{y}$. Accessed 20 January 2022.

Horne, L., S. De Urioste-Stone, and J. Daigle. 2021. Climate change adaptation and mitigation in the face of local uncertainty: A phenomenological study. Northeastern Naturalist 28(Special Issue 11):108-128.

Hoving, C.L., D.J. Harrison, W.B. Krohn, R.A. Joseph, and M. O'Brien. 2005. Broad-scale predictors of Canada Lynx occurrence in eastern North America. Journal of Wildlife Management 69:739-751. https://doi.org/10.2193/0022-541X(2005)069[0739:BPOCL O]2.0.CO;2.

Huntington, T.G., G.A. Hodgkins, B.D. Keim, and R.W. Dudley. 2004. Changes in the proportion of precipitation occurring as snow in New England (1949-2000). Journal of Climate 17:2626-2636. https://doi.org/10.1175/1520-0442(2004)017<2626:CITPOP $>2$ $.0 . \mathrm{CO} ; 2$.

Jackson, N., and J. Puccinelli. 2006. Long-term pavement performance (LTPP) data analysis support: National pooled fund study TPF-5 (013)-effects of multiple freeze cycles and deep frost penetration on pavement performance and cost (No. FHWA-HRT-06-121). US Department of Transportation Federal Highway Administration, Washington, DC. 265 pp. Available online at: https://www.fhwa.dot.gov/publications/research/infrastructure/ pavements/ltpp/06121/06121.pdf. Accessed 20 January 2022.

Karmalkar, A., and R.S. Bradley. 2017. Consequences of global warming of $1.5^{\circ} \mathrm{C}$ and 2 ${ }^{\circ} \mathrm{C}$ for regional temperature and precipitation changes in the contiguous United States. PLOS ONE 12(1):e0168697. https://doi.org/10.1371/journal.pone.0168697. 
Krohn, W.B., K.D. Elowe, and R.B. Boone. 1995. Relations among Fishers, snow, and Martens: Development and evaluation of two hypotheses. The Forestry Chronicle 71:97-105. https://doi.org/10.5558/tfc71097-1.

Kwiatkowski, K.P., I. Stipanovic Oslakovic, H. Ter Maat, A. Hartmann, P. Chinowsky, and G.P. Dewulf. 2020. Modeling cost impacts and adaptation of freeze-thaw climate change on a porous asphalt road network. Journal of Infrastructure Systems 26(3):04020022.

Leighton, P.A., J.K. Koffi, Y. Pelcat, L.R. Lindsay, and N.H. Ogden. 2012. Predicting the speed of tick invasion: An empirical model of range expansion for the Lyme disease vector Ixodes scapularis in Canada. Journal of Applied Ecology 49:457-464. https://doi. org/10.1111/j.1365-2664.2012.02112.x.

Lesk, C., E. Coffel, A.W. D’Amato, K. Dodds, and R. Horton. 2017. Threats to North American forests from Southern Pine Beetle with warming winters. Nature Climate Change 7:713-717. https://doi.org/10.1038/nclimate3375.

Levi, T., F. Keesing, K. Oggenfuss, and R.S. Ostfeld. 2015. Accelerated phenology of Blacklegged Ticks under climate warming. Philosophical Transactions of the Royal Society B 370:1-8. https://doi.org/10.1098/rstb.2013.0556.

Liptzin, D., M.W. Williams, D. Helmig, B. Seok,G. Filippa, K. Chowanski, and J. Hueber. 2009. Process-level controls on $\mathrm{CO}_{2}$ fluxes from a seasonally snow-covered subalpine meadow soil, Niwot Ridge, Colorado. Biogeochemistry 95:151-166. https://doi. org/10.1007/s10533-009-9303-2.

Livneh B., E.A. Rosenberg C. Lin, B. Nijssen, V. Mishra, K.M. Andreadis, E.P. Maurer and D.P. Lettenmaier. 2013. A long-term hydrologically based dataset of land-surface fluxes and states for the conterminous United States: Update and extensions. Journal of Climate 26:9384-9392. https://doi.org/10.1175/JCLI-D-12-00508.1.

Livneh, B., E.A. Rosenberg, C. Lin, B. Nijssen, and V. Mishra. 2014. A long-term hydrologically based dataset of land surface fluxes and states for the conterminous United States: Update and extensions. Journal of Climate 27:478-486. https://doi.org/10.1175/ JCLI-D-12-00508.1

Lynch, C., A. Seth, and J. Thibeault. 2016. Recent and projected annual cycles of temperature and precipitation in the Northeast United States from CMIP5. Journal of Climate 29:347-365. https://doi.org/10.1175/JCLI-D-14-00781.1.

Maloney, E.D., S.J. Camargo, E. Chang, B. Colle, R. Fu, K.L. Geil, Q. Hu, X. Jiang, et al. 2014. North American climate in CMIP5 experiments: Part III: Assessment of twentyfirst-century projections. Journal of Climate 27:2230-2270. https://doi.org/10.1175/ JCLI-D-13-00273.1.

Mann, H.B. 1945. Non-parametric test against trend. Econometrica 13:245-259.

Maurer, E.P., H.G. Hidalgo, T. Das, M.D. Dettinger, and D.R. Cayan. 2010. The utility of daily large-scale climate data in the assessment of climate change impacts on daily streamflow in California. Hydrology and Earth System Sciences 14:1125-1138, https:// doi.org/10.5194/hess-14-1125-2010.

McClure, M.S. 1990. Role of wind, birds, deer, and humans in the dispersal of Hemlock Woolly Adelgid (Homoptera, Adelgidae). Environmental Entomology 20:258-264. https://doi.org/10.1093/ee/19.1.36.

Mearns, L.O., W. J. Gutowski, R. Jones, L.-Y. Leung, S. McGinnis, A.M.B. Nunes, and Y. Qian. 2009. A regional climate-change assessment program for North America. EOS 90(36):311-312. https://doi.org/10.1029/2009EO360002.

Merriam, G., J. Wegner, and D. Caldwell. 1983. Invertebrate activity under snow in a deciduous woods. Holarctic Ecology 6:89-94. 
Milling, C.R., J.L. Rachlow, M.A. Chappell, M.J. Camp, T.R. Johnson, L.A. Shipley, D.R. Paul, and J.S. Forbey. 2018. Seasonal temperature acclimatization in a semifossorial mammal and the role of burrows as thermal refuges. PeerJ 6:e4511. https://doi. org/10.7717/peerj.4511.

Monson, R.K., D.L. Lipson, S.P. Burns, A. Turnipseed, A.C. Delany, M.W. Williams, and S.K. Schmidt. 2005. Winter forest-soil respiration controlled by climate and microbial community composition. Nature 439:711-714. https://doi.org/10.1038/nature04555.

Morin, S., R. Samacoïts, H. François, C. Carmagnola, B. Abegg, O.C. Demiroglu, M. Pons, J.-M. Soubeyroux, et al. 2021. Pan-European meteorological and snow indicators of climate change impact on ski tourism. Climate Services 22:100215. https://doi. org/10.1016/j.cliser.2021.100215.

Murray, G.L.D., .M. Colgan, S.J. Nelson, E.P. Kelsey, and K.D. Kimball. 2021. Climate trends on the highest peak of the Northeast: Mount Washington, NH. Northeastern Naturalist 28(Special Issue 11):64-82.

New York Department of Environmental Conservation. 2021. Southern Pine Beetle. Available online at https://www.dec.ny.gov/animals/99331.html. Accessed 15 September 2021.

Ning, L., and R.S. Bradley. 2015. Snow occurrence change over the central and eastern United States under future warming scenarios. Scientific Reports 5:17073. https://doi. org/10.1038/srep17073.

Ogden, N.H., R. Milka, C. Caminade, and P. Gachon. 2014. Recent and projected future climatic suitability of North America for the Asian Tiger Mosquito, Aedes albopictus. Parasites and Vectors 7:532. https://doi.org/10.1186/s13071-014-0532-4.

Paradis, A., J. Elkinton, K. Hayhoe, and J. Buonaccorsi. 2008. Role of winter temperature and climate change on the survival and future range expansion of the Hemlock Woolly Adelgid (Adelges tsugae) in eastern North America. Mitigation and Adaptation Strategies to Global Change 13:541-544. https://doi.org/10.1007/s11027-007-9127-0.

Parker, B.L., M. Skinner, S. Gouli, T. Ashikaga, and H.B. Teillon. 1999. Low lethal temperature for Hemlock Woolly Adelgid (Homoptera: Adelgidae). Environmental Entomology 6:1086-1091. https://doi.org/10.1093/ee/28.6.1085.

Patel, K.F., C. Tatariw, J.D. MacRae, T. Ohno, S.J. Nelson, and I.J. Fernandez. 2018. Soil carbon and nitrogen responses to snow removal and concrete frost in a northern coniferous forest. Canadian Journal of Soil Science 98:1-12. https://doi.org/10.1139/ cjss-2017-0132.

Pauli, J.N., B. Zuckerberg, J.P. Whiteman, and W. Porter. 2013. The subnivium: A deteriorating seasonal refugium. Frontiers in Ecology and the Environment 11(5):260-267. https://doi.org/10.1890/120222.

Penczykowski, R.M., B.M Connolly, and B.T. Barton. 2017. Winter is changing: Trophic interactions under altered snow regimes. Food Webs 13:80-91. https://doi.org/10.1016/j. fooweb.2017.02.006.

Perlwitz, J., T. Knutson, J.P. Kossin, and A.N. LeGrande. 2017. Large-scale circulation and climate variability. Pp. 161-184, In D.J. Wuebbles, D.W. Fahey, K.A. Hibbard, D.J. Dokken, B.C. Stewart, and T.K. Maycock (Eds.). Climate Science Special Report: Fourth National Climate Assessment, Volume I. US Global Change Research Program, Washington, DC. 470 pp. https://doi.org/10.7930/J0RV0KVQ.

Pierce, D.W., D.R. Cayan, and B.L. Thrasher. 2014. Statistical downscaling using localized constructed analogs. Journal of Hydrometeorology 15:2558-2585. https://doi. org/10.1175/JHM-D-14-0082.1. 
Platonov, A.E., M.V. Fedorova, L.S. Karan, T.A. Shopenskaya, O.V. Planova, and V.I. Zhuravlev. 2008. Epidemiology of West Nile infection in Volgograd, Russia, in relation to climate change and mosquito (Diptera: Culicidae) bionomics. Parasitology Research 103:S45-S53. https://doi.org/10.1007/s00436-008-1050-0.

Pruitt, W.O., Jr. 1970. Some ecological aspects of snow. Pp. 83-99, In Proceedings of the 1966 Helsinki Symposium on ecology of the subarctic regions, UNESCO Series, Ecology and Conservation 1, Paris, France. 364 pp.

Rawlins, M.A., R.S. Bradley, H.F. Diaz, J.S. Kimball, and D.A. Robinson. 2016. Future decreases in freezing days across North America. Journal of Climate 29:6923-6935. https://doi.org/10.1175/JCLI-D-15-0802.1.

Riahi, K., S. Rao, V. Krey, C. Cho, V. Chirkov, G. Fischer, G. Kindermann, N. Nakicenovic, and P. Rafaj. 2011. RCP8.5-A scenario of comparatively high greenhouse gas emissions. Climatic Change 109:33-57. https://doi.org/10.1007/s10584-011-0149-y.

Rittenhouse, C.D., and A.R. Rissman. 2015. Changes in winter conditions impact forest management in north temperate forests. Journal of Environmental Management 149:157-67. https://doi.org/10.1016/j.jenvman.2014.10.010.

Rochlin, I., D.V. Ninivaggi, M.L. Hutchinson, and A. Farajollahi. 2013. Climate change and range expansion of the Asian Tiger Mosquito (Aedes albopictus) in Northeastern USA: Implications for public health practitioners. PLoS ONE 8:e60874. https://doi. org/10.1371/journal.pone.0060874.

Sanders-DeMott, R., R. McNellis, M. Jabouri, and P.H. Templer. 2018. Snow depth, soil temperature, and plant-herbivore interactions mediate plant response to climate change. Journal of Ecology 106:1508-1519. https://doi.org/10.1111/1365-2745.12912.

Sanders-DeMott, R., A.P. Ouimette, L.C. Lepine, S. Fogarty, E.A. Burakowski, A.R. Contosta, and S.V. Ollinger. 2020. Divergent carbon cycle response of forest and grassdominated northern temperate ecosystems to record winter warming. Global Change Biology 26(3):1519-1531. https://doi.org/10.1111/gcb.14850.

Schwartz, M.D., R. Ahas, and A. Aasa. 2006. Onset of spring starting earlier across the Northern Hemisphere. Global Change Biology 12:343-351. https://doi.org/10.1111/ j.1365-2486.2005.01097.x.

Scott D., G. McBoyle, and B. Mills. 2003. Climate change and the skiing industry in Southern Ontario (Canada): Exploring the importance of snowmaking as a technical adaptation. Climate Research 23:171-181.

Scott, D., J. Dawson, and B. Jones. 2008. Climate change vulnerability of the US Northeast winter recreation-tourism sector. Mitigation and Adaptation Strategies for Global Change 13(5-6):577-596.

Scott, D., R. Steiger, M. Rutty, and P. Johnson. 2015. The future of the Olympic Winter Games in an era of climate change. Current Issues in Tourism 18(10):913-930. https:// doi.org/10.1080/13683500.2014.887664.

Scott, D., R. Steiger, N. Knowles, and Y. Fang. 2020. Regional ski tourism risk to climate change: An inter-comparison of Eastern Canada and US Northeast markets. Journal of Sustainable Tourism 28(4):568-586. https://doi.org/10.1080/09669582.2019.1684932.

Sen, P.K. 1968. Estimates of the regression coefficient based on Kendall's Tau. Journal of the American Statistical Association 63:1379-1389. https://doi.org/10.1080/01621459. 1968.10480934.

Shanley, J.B., and A. Chalmers. 1999. The effect of frozen soil on snowmelt runoff at Sleepers River, Vermont. Hydrological Processes 13:1843-1857. https://doi.org/10.1002/ (SICI)1099-1085(199909)13:12/13<1843::AID-HYP879>3.0.CO;2-G. 
Shields, K.S., and C.A. Cheah. 2005. Winter mortality in Adelges tsugae populations in 2003 and 2004. Pp. 354-356, In K.W. Gottschalk (Ed.). Proceedings of the $16^{\text {th }}$ US Department of Agriculture interagency research forum on gypsy moth and other invasive species, 18-21 January 2005, Annapolis, MD. USDA Forest Service General Technical Report NE-337. US Department of Agriculture, Forest Service, Northeastern Research Station, Newtown, PA. 107 pp..

Skinner, M., B.L. Parker, S. Gouli, and T. Ashikaga. 2003. Regional responses of Hemlock Woolly Adelgid (Homoptera: Adelgidae) to low temperatures. Environmental Entomology 32:523D528. https://doi.org/10.1603/0046-225X-32.3.523.

Sømme, L. 1982. Supercooling and winter survival in terrestrial arthropods. Comparative Biochemical Physiology A 73(4):519-543. https://doi.org/10.1016/03009629(82)90260-2.

Sommerfeld, R.A., A.R. Mosier, and R.C. Musselman. 1993. $\mathrm{CO}_{2}, \mathrm{CH}_{4}$, and $\mathrm{N}_{2} \mathrm{O}$ flux through a Wyoming snowpack and implications for global budgets. Nature 361:140 142. https://doi.org/10.1038/361140a0.

Sorensen, P.O., A.C. Finzi, M.-A. Giasson, A.B. Reinmann, R.S. Sanders-DeMott, and P.H. Templer. 2018. Winter soil freeze-thaw cycles lead to reductions in soil microbial biomass and activity not compensated for by soil warming. Soil Biology and Biochemistry 116:39-47. https://doi.org/10.1016/j.soilbio.2017.09.026.

Steiger, R. 2010. The impact of climate change on ski season length and snowmaking requirements in Tyrol, Austria. Climate Research 43(3):251-262.

Steiger R, and M. Mayer. 2008. Snowmaking and climate change: Future options for snow production in Tyrolean ski resorts. Mountain Research and Development 28(3-4):292298. https://doi.org/10.1659/mrd.0978.

Tatariw, C., K. Patel, J.D. MacRae, and I.J. Fernandez. 2017. Snowpack loss promotes soil freezing and concrete frost formation in a northeastern temperate softwoods stand. Northeastern Naturalist 24(Special Issue 7):B42-B54.

Templer, P.H., A.F. Schiller, N.W. Fuller, A.M. Socci, J.L. Campbell, J.E. Drake, and T.H. Kunz. 2012. Impact of a reduced winter snowpack on litter arthropod abundance and diversity in a Northern Hardwood Forest Ecosystem. Biology and Fertility of Soils 48:413-424. https://doi.org/10.1007/s00374-011-0636-3.

Thibeault, J., and A. Seth. 2014. Changing climate extremes in the Northeast United States: Observations and projections from CMIP5. Climatic Change 127(2):273-287. https:// doi.org/10.1007/s10584-014-1257-2.

Thompson, K.L., B. Zuckerberg, W.P. Porter, and J.N. Pauli. 2021. The decline of a hidden and expansive microhabitat: The subnivium. Frontiers in Ecology and the Environment 19(5):268-273. https://doi.org/10.1002/fee.2337.

Thomson, A., K.V. Calvin, S.J. Smith, G.P. Kyle, A. Volke, P. Patel, S. Delgado-Arias, B. Bond-Lamberty, M.A. Wise, L.E. Clarke, and J.A. Edmonds. 2011. RCP4.5: A pathway for stabilization of radiative forcing by 2100. Climatic Change 109:77-94. https://doi. org/10.1007/s10584-011-0151-4.

Ungerer, M.J., M.P. Ayers, and M.J. Lombardero. 1999. Climate and northern distribution limits of Dendroctonus frontalis Zimmerman (Coleoptera: Scolytidae). Journal of Biogeography 26(6):1133-1145.

Vörösmarty, C.J., C.A. Federer, and A.L. Schloss. 1998. Potential evaporation functions compared on US watersheds: Implications for global-scale water balance and terrestrial ecosystem modeling, Journal of Hydrology 207:147-169. https://doi.org/10.1016/ S0022-1694(98)00109-7. 
Wake, C.P., J. Knott, T. Lippman, M.D. Stampone, T.P. Ballestero, D. Bjerklle, E. Burakowski, S.J. Glidden, I. Hosseini-Shakib, and J.M. Jacobs. 2019. New Hampshire coastal flood risk summary. Part 1: Science. Prepared for the New Hampshire Coastal Flood Risk Science and Technical Advisory Panel. Report published by the University of New Hampshire, Durham, NH. 80 pp. https://doi.org/10.34051/p/2019.1.

Wang, C., Y. Han, J. Chen, X. Wang, Q. Zhang, and B. Bond-Lamberty. 2013. Seasonality of soil $\mathrm{CO}_{2}$ efflux in a temperate forest: Biophysical effect of snowpack and spring freezethaw cycles. Agricultural and Forest Meteorology 177:83-92. https://doi.org/10.1016/j. agrformet.2013.04.008.

Weed, A.S., M.P. Ayres, and J.A. Hicke. 2013. Consequences of climate change for biotic disturbances in North American forests. Ecological Monographs 83:441-470. https:// doi.org/10.5061/dryad.cq1r1.

Wilson, G., M. Green, and K. Mack. 2018. Historical climate warming in the White Mountains of New Hampshire (USA): Implications for snowmaking watern at ski areas. Mountain Research and Development 38(2):164-171. https://doi.org/10.1659/MRDJOURNAL-D-17-00117.

Wisser, D., B.M. Fekete, C.J. Vörösmarty, A.H. Schumann. 2010. Reconstructing $20^{\text {th }}$ century global hydrography: A contribution to the Global Terrestrial Network- Hydrology (GTN-H). Hydrology and Earth System Science 14:1-24. https://doi.org/10.5194/ hess-14-1-2010.

Wobus, C., E.E. Small, H. Hosterman, D. Mills, J. Stein, M. Rissing, R. Jones, M. Duckworth, R. Hall, M. Kolian, J. Creason, and J. Martinich. 2017. Projected climate-change impacts on skiing and snowmobiling: A case study of the United States. Global Environmental Change 45:1-14. https://doi.org/10.1016/j.gloenvcha.2017.04.006.

Wood, A.W., L.R. Leung, V. Srdhar, and D.P. Lettenmaier. 2004. Hydrologic implications of dynamical and statistical approaches to downscaling climate model outputs. Climatic Change 62:189-216. https://doi.org/10.1023/B:CLIM.0000013685.99609.9e.

Wuebbles, D.J., D.W. Fahey, K.A. Hibbard, D.J. Dokken, B.C. Stewart, and T.K. Maycock (Eds.). 2017. Climate Science Special Report: Fourth National Climate Assessment, Volume I. US Global Change Research Program, Washington, DC. 470 pp. https://doi. org/10.7930/J0J964J6.

Zhu, L., A.R. Ives, C. Zhang, Y. Guo, and V.C. Radeloff. 2019. Climate change causes functionally colder winters for snow cover-dependent organisms. Nature Climate Change 9:886-893. https://doi.org/10.1038/s41558-019-0588-4. 